\title{
Contribution to the knowledge of Choroterpes (Ephemeroptera: Leptophlebiidae)
}

\section{K познанию Choroterpes (Ephemeroptera: Leptophlebiidae)}

\author{
Nikita J. Kluge \\ Н.Ю. КАюге
}

Department of Entomology, St. Petersburg State University, Universitetskaya nab., 7/9, St. Petersburg 199034, Russia. E-mail: kluge@FK13889.spb.edu. Website: http://www.insecta.bio.pu.ru

Кафедра энтомологии, биолого-почвенный факультет, С.-Петербургский государственный университет, Университетская наб., 7/8, С.-Петербург 199034, Россия.

KEY WORDS: systematics, Ephemeroptera, Leptophlebiidae, Atalophlebomaxillata, Choroterpes, Neochoroterpes, Euthraulus, Monophyllus, Dilatognathus, Choroterpides, new species.

КЛЮЧЕВЫЕ СЛОВА: систематика, Ephemeroptera, Leptophlebiidae, Atalophlebomaxillata, Choroterpes, Neochoroterpes, Euthraulus, Monophyllus, Dilatognathus, Choroterpides, новые виды.

ABSTRACT. The taxon Atalophlebomaxillata is characterized by presence of an apical flange on maxilla; this flange is lost only in those representatives, whose maxillae are highly specialized. Within AtalophlebomaxillataAtalophlebolinguata, a new tribe Choroterpini tribus n. (or Choroterpes/fg1) is established, to comprise Thraulus and Choroterpes s.l. (or Choroterpes/fg2). The taxon Choroterpes/fg2 is divided into Choroterpes/fg3 (characterized by lanceolate median filaments on tergalii) and Euthraulus/g1 (characterized by arched penial arms). Choroterpes/fg3 includes a widely distributed plesiomorphon Choroterpes/fg4 and a Nearctic taxon Neochoroterpes. Based on imagoes reared from larvae, new species and subspecies of Choroterpes/fg4 are described - Ch. (Ch.) picteti subcostalis ssp.n. from Caucasus (Russia), Ch. (Ch.) ludmilae sp.n. from Oman and Ch. (Ch.) mercatorius sp.n. from Sulawesi Island (Indonesia). The taxon Euthraulus/g1 has exclusively Old-World distribution; it includes widely distributed plesiomorphon Euthraulus/g2 and two small Oriental taxa - Monophyllus subgen.n. and Dilatognathus subgen.n. Based on imagoes reared from larvae, a new species of Euthraulus/g2 is described - Ch. (Euthraulus) caucasicus sp.n., and additional descriptions to $C h$. (E.) altioculus, Ch. (E.) sumbarensis and Ch. (E.) signatus are given. The taxon Monophyllus includes a single species Ch. (Monophyllus) monophyllus sp.n., described as mature larvae from Hainan Island (China). Larvae of the taxon Dilatognathus are known under the generic name Choroterpides, whose type species (exiguus Eaton, 1884 [Thraulus]) is known only as imago and probably belongs to Euthraulus/g2. The type species of Dilatognathus is Choroterpes (Dilatognathus) cataractae sp.n., described as imagoes reared from larvae in Lombok Island (Indonesia). Similar modifications in mouthparts structure independently evolved in non-related taxa Dilatognathus, Notophlebia, Hermanellognatha, Hagenulus/fg3 and Ulmeritus/g2.
РЕЗЮМЕ. Таксон Atalophlebomaxillata характеризуется наличием апикальной пластинки на максилле; эта пластинка утрачена только у тех представителей, максиллы которых сильно специализированы. В составе Atalophlebomaxillata-Atalophlebolinguata выделяется новая триба Choroterpini tribus n. (или Choroterpes/fg1), объединяющая Thraulus и Choroterpes s.1. (или Choroterpes/fg2). Таксон Choroterpes/fg2 делится на Choroterpes/fg3 (характеризующийся ланцетовидным медиальным филаментом тергалий) и Euthraulus/g1 (характеризующийся дуговидными руками пениса). Choroterpes/fg3 включает широко распространённый плезиоморфон Choroterpes/fg4 и неарктический таксон Neochoroterpes. По имаго, выведенным из личинок, описываются новые виды и подвиды Choroterpes/fg4 - Ch. (Ch.) picteti subcostalis ssp.n. с Кавказа (Россия), Ch. (Ch.) ludmilae sp.n. из Омана и Ch. (Ch.) mercatorius sp.n. с о. Сулавеси (Индонезия). Таксон Euthraulus/g1 известен исключительно из Старого Света; он включаетширокораспространённый плезиоморфон Euthraulus/ g2 и два маленьких ориентальных таксона Monophyllus subgen.n. и Dilatognathus subgen.n. По имаго, выведенным из личинок, описывается новый вид Euthraulus/g2 - Ch. (Euthraulus) caucasicus sp.n., а также даются дополнительные описания $C h .(E$. altioculus, Ch. (E.) sumbarensis и Ch. (E.) signatus. Таксон Monophyllus включает единственный вид $C h$. (Monophyllus) monophyllus sp.n., описанный по зрелым личинкам с о. Хайнань (Китай). Личинки Dilatognathus известны под родовым названием Choroterpides, типовой вид которого (exiguus Eaton, 1884 [Thraulus]) известен только по имаго и, вероятно, относится к Euthraulus/g2. Типовым видом Dilatognathus subgen.n. является Choroterpes (Dilatognathus) cataractae sp.n., описанный по имаго, выведенным из личинок на о. Ломбок (Индонезия). Сход- 
ные преобразования в строении ротовых частей независимо произошли у неродственных таксонов Dilatognathus, Notophlebia, Hermanellognatha, Hagenulus/fg3 и Ulmeritus/g2.

\section{Introduction}

This paper continues revision of mayfly system based on the principles of cladoendesis [Kluge \& Novikova, 2011; Kluge, 1912] with usage of the dual nomenclature system [Kluge, 2010]. Based on these principles, instead of the formal subfamily Atalophlebiinae, a series of subsequently subordinated rank-free taxa have been established: Atalophleboadentata (or Atalophlebia/fg1) $>$ Atalophlebopectinata (or Atalophlebia/fg2) > Atalophleboculata (or Atalophlebia/fg3) > Atalophlebomaxillata (or Atalophlebia/fg4) > Atalophlebolinguata (or Atalophlebia/fg5) [Kluge, 2004, 2008, 2009]. The phylogenetic relationships within the taxon Atalophlebolinguata remain poorly known. Within Atalophlebolinguata, a subordinated holophyletic taxon Hagenulus/fg1 has been established [Kluge, 2008].

In the present paper, based on new material, the taxon Atalophlebomaxillata is redefined and a new holophyletic taxon Choroterpes/fg1 within Atalophlebolinguata is established. Classification of the taxa discussed in this paper is the following:

1. Atalophlebomaxillata

1.1. Atalophlebolinguata

1.1.1. Choroterpes/fg1 (incl. Thraulus)

1.1.1.1. Choroterpes/fg2 (incl. Euthraulus)

1.1.1.1.1. Choroterpes/fg3 (incl. Neochoroterpes)

1.1.1.1.1.1. Plesiomorphon Choroterpes/fg4

1.1.1.1.1.1-1. Choroterpes/fg4 picteti [Choroterpes]

1.1.1.1.1.1-1.1. Choroterpes/fg4 p. picteti [Choroterpes]

1.1.1.1.1.1-1.2. Choroterpes/fg4 p. subcostalis ssp.n. [Choroterpes]

1.1.1.1.1.1-2. Choroterpes/fg4 nigrescens [Choroterpes]

1.1.1.1.1.1-3. Choroterpes/fg4 ludmilae sp.n. [Choroterpes]

1.1.1.1.1.1-4. Choroterpes/fg4 mercatorius sp.n. [Choroterpes]

1.1.1.1.1.2. Neochoroterpes/g(1), or Neochoroterpes

1.1.1.1.1.2-1. Neochoroterpes/g(1) oklahoma [Choroterpes]

1.1.1.1.2. Euthraulus/g1 (incl. Monophyllus, Dilatognathus)

1.1.1.1.2.1. Plesiomorphon Euthraulus/g2

1.1.1.1.2.1-1. Euthraulus/g2 altioculus [Choroterpes]

1.1.1.1.2.1-2. Euthraulus/g2 sumbarensis [Choroterpes]

1.1.1.1.2.1-3. Euthraulus/g2 caucasicus sp.n. [Choroterpes]

1.1.1.1.2.1-4. Euthraulus/g2 signata [Cloe]

1.1.1.1.2.1-5. Euthraulus/g2 bugandensis [Euthraulus]

1.1.1.1.2.2. Monophyllus/g(1), or Monophyllus subgen.n.

1.1.1.1.2.2-1. Monophyllus/g(1) monophyllus sp.n. [Choroterpes]

1.1.1.1.2.3. Dilatognathus/g(1), or Dilatognathus subgen.n.

1.1.1.1.2.3-1. Dilatognathus/g(1) cataractae sp.n. [Choroterpes]

1.1.1.1.2.3-2. Dilatognathus/g(1) sp.1

1.1.1.1.2.3-3. Dilatognathus/g(1) sp.2

1.1.1.1.2.3-4. Dilatognathus/g(1) sp.3

1.1.1.1.2.3-5. Dilatognathus/g(1) sp.4

All material, including holotypes and paratypes of new species, will be permanently deposited in the Zoological Institute of Russian Academy of Sciences (Saint
Petersburg, Russia), but is temporarily located in the Department of Entomology of Saint Petersburg State University. In the lists of material examined, the following arbitrary signs are used: $\mathbf{L}$ - larva; $\mathbf{S}$ - subimago; $\mathbf{I}$ - imago; L-S-I $\sigma^{\boldsymbol{T}}$ - male imago reared from larva, with larval and subimaginal exuviae; L-S-I + — female imago reared from larva, with larval and subimaginal exuviae; $\mathbf{L - S} \sigma^{7}$ - male subimago reared from larva, with subimaginal exuviae; L/S $\widetilde{S}^{\top}-$ male subimago extracted from mature larva.

\section{Atalophlebomaxillata, or Atalophlebia/fg4}

Systematic position: Leptophlebia/fg1-AtalophleboadentataAtalophlebopectinata-Atalophleboculata-Atalophlebomaxillata.

Circumscriptional name: Atalophlebomaxillata Kluge, 2009.

Hierarchical typified name: Atalophlebia/fg4 (sine Terpides; incl. Castanophlebia).

Possible rank-based name:

- subfamily Atalophlebiinae s.1.

\section{Autapomorphies.}

(1) Maxilla has an apical flange, which represent a continuation of its ventral wall to apical direction and separates the apical field of long filtering setae (characteristic for Leptophlebia/fg1) from the apical-ventral row of pectinate setae (also characteristic for Leptophlebia/fg1); thanks to the apical flange, the apical field of long filtering setae is shifted to the dorsal side of maxilla and its ventral margin locates far from the apical-ventral row of pectinate setae (Fig. 3). The apical flange reaches inner margin of maxilla, and laterally terminates fare from outer margin of maxilla (Fig. 2). The apical flange is very thin and translucent, so it is poorly visible on background of dense apical filtering setae. In my previous paper maxilla of Farrodes bimaculatus Peters \& Alayo, 1971 was shown wrongly, without the apical flange [Kluge, 1994: Fig.4]; actually it has the apical flange similar to that in Fig. 2.

Among the taxa examined, the apical flange is reduced only in taxa with highly specialized maxillae of the «Dilatognathus-like type» — Hermanellognatha [Kluge, 2008: Fig. 37], Notophlebia Peters \& Edmunds, 1970, Hagenulus morrisonae Peters \& Alayo, 1971 (but not Hagenulus caligatus Eaton, 1882) and last instar larva of Dilatognathus subgen.n. (Fig. 129) (but not its younger larvae - Fig. 132).

Unlike Atalophlebomaxillata, in other Leptophlebia/fg1 (i.e., Terpides/fg1, Habrophlebia/fg1, Calliarcys/fg(1) and the plesiomorphon Leptophlebia/fg2) the apical flange is absent, the apical field of long filtering setae is located at most on ventral side of maxilla, and its ventral margin is located close to the apical-ventral row of pectinate setae (Fig. 1) [Kluge, 2009: Fig.1].

(2) Distal dentiseta is usually lost, so maxilla has a single pectinate dentiseta (which is originally the proximal one) (Figs 2, 4, 5).

Discussion. In the previous papers [Kluge, 2008, 2009] I characterized the taxon Atalophlebia/fg4, or Atalophlebomaxillata, by a single autapomorphy - loss of the distal dentiseta. However, Aprionyx Barnard, 1940 has the distal dentiseta retained; its distal dentiseta is somewhat smaller than in Terpides/fgl and can be poorly visible, being pressed to the dense apical filtering setae. At the same time, hypopharynx of Aprionyx has a pair of processes typical for Atalophlebolinguata. Some individuals of Atalophlebomaxillata have the single dentiseta bifurcate, with a slender nonpectinate distal branch; possibly, this branch is a vestige of the distal dentiseta basally fused with the proximal dentise- 


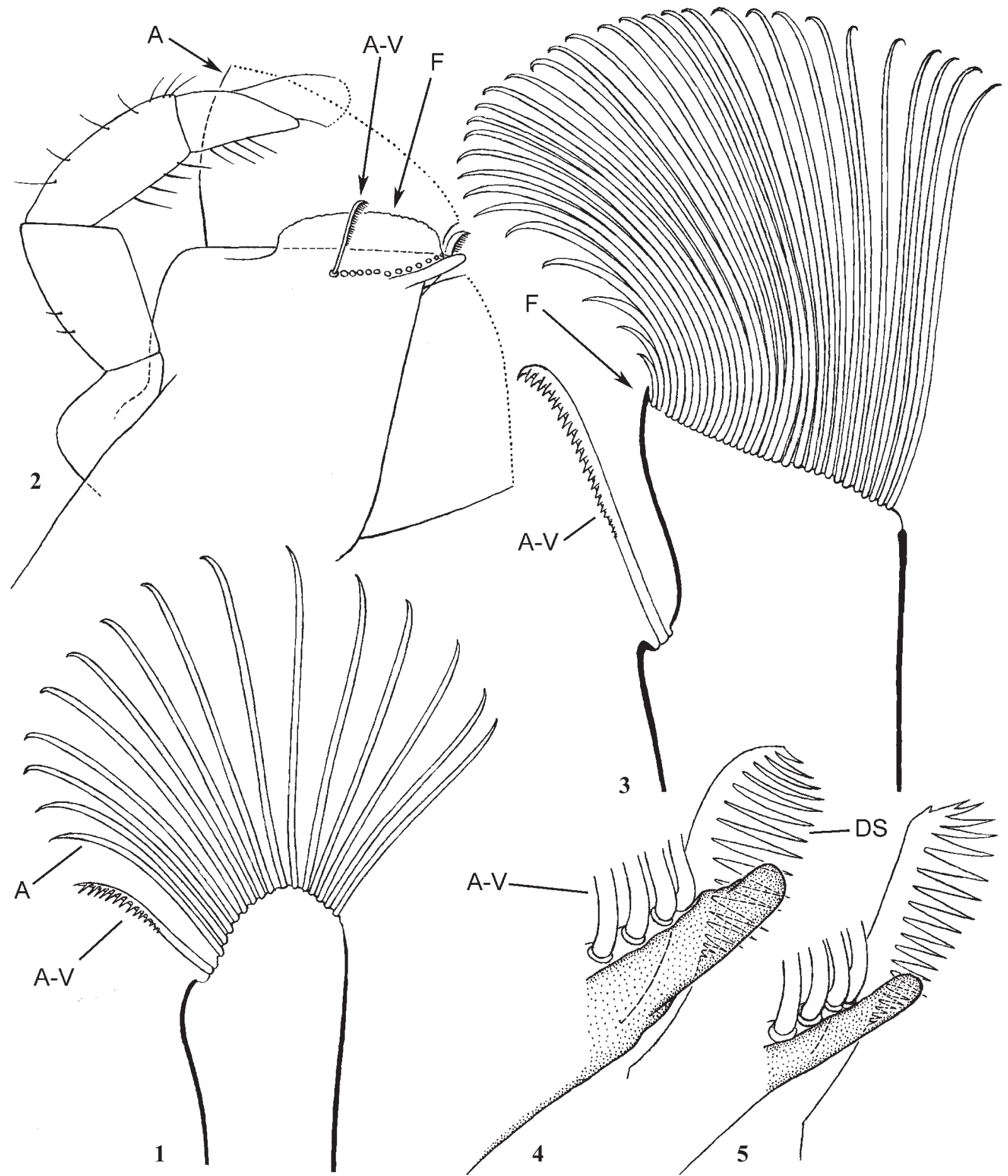

Figs 1-5. Maxilla. 1 - Terpides (Fittkaulus) amazonicus Kluge, 2009, transverse section of maxilla through apical field of long filtering setae and apical-ventral row of pectinate setae; $2-4$ - Choroterpes (Choroterpes) picteti subcostalis sp.n.: 2 - ventral view (most part of setae not shown, areas occupied by them shown by dotted lines; instead of pectinate setae of apical-ventral row, their bases are shown); 3 — transverse section of maxilla through apical field of long filtering setae and apical-ventral row of pectinate setae; 4 - medio-apical projection, ventral view (dotted); 5 - Ch. (Ch.) picteti picteti, the same. A - apical field of long filtering setae; $\mathbf{A}-\mathbf{V}-$ pectinate seta of apical-ventral row; DS - dentiseta; $\mathbf{F}$ - apical flange.

Рис 1-5. Максилла. 1 - Terpides (Fittkaulus) amazonicus Kluge, 2009, поперечный срез максиллы через апикальное поле длинных фильтрующих щетинок и апикально-вентральный ряд гребенчатых щетинок; 2-4 - Choroterpes (Choroterpes) picteti subcostalis sp.n.: 2 - вентрально (большая часть щетинок не показана, занимаемые области показаны точечными линиями; вместо гребенчатых щетинок апикально-вентрального ряда показаны их основания); 3 - поперечный срез максиллы через апикальное поле длинных фильтрующих щетинок и апикально-вентральный ряд гребенчатых щетинок; 4 - медио-апикальный выступ, вентрально (пунктирован); 5 - Ch. (Ch.) picteti picteti, то же. A - апикальное поле длинных фильтрующих щетинок; A-V - гребенчатые щетинки апикально-вентрального ряда; DS - дентисета; $\mathbf{F}$ - апикальная пластинка. 
ta; if this is so, presence of such branch is a transitional condition between presence of the distal dentiseta and its absence. The apical flange, described above, seems to be more reliable character of Atalophlebomaxillata, than the loss of distal dentiseta.

Classification. The taxon Atalophlebomaxillata is divided into a small South African taxon Castanophlebia/fg1 and a large taxon Atalophlebolinguata.

\subsection{Atalophlebolinguata Kluge, 2009, or Atalophlebia/fg5}

Systematic position: Leptophlebia/fg1-AtalophleboadentataAtalophlebopectinata-Atalophleboculata-Atalophlebomaxillata-Atalophlebolinguata.

Circumscriptional name: Atalophlebolinguata Kluge, 2009.

Hierarchical typified name: Atalophlebia/fg5 (sine Castanophlebia). Possible rank-based name:

- subfamily Atalophlebiinae s.str.

Autapomorphy. The taxon Atalophlebolinguata is characterized by presence of a pair of lateral arched processes on hypopharynx [Kluge, 2009]. These processes never undergo reduction and are retained in all representatives of Atalophlebolinguata, independently of specialization of their mouthparts.

Classification. The taxon Atalophlebolinguata includes majority of Leptophlebiidae; its phylogeny is still unclear. Among numerous taxa, which constitute Atalophlebolinguata, I had already characterized the holophyletic taxon Hagenulus/fg1 with Neotropical distribution [Kluge, 2008]. Here is characterized the taxon Choroterpes/fg1, whose distribution is mainly Old-World.

\subsubsection{Choroterpes/fg1}

Systematic position: Leptophlebia/fg1-AtalophleboadentataAtalophlebopectinata-Atalophleboculata-Atalophlebomaxillata-Atalophlebolinguata-Choroterpes/fg1.

Hierarchical typified name: Choroterpes/fg1 (incl. Thraulus Eaton, 1881) [f: Choroterpini tribus n.; g: Choroterpes Eaton, 1881; type species: Ch. lusitanica Eaton, 1881 (synonym of Leptophlebia picteti Eaton, 1871)].

Possible rank-based name:

- tribus Choroterpini.

Autapomorphies.

(1) Difference between tergalius I and tergalii II-VII is more or less expressed: tergalius I tends to narrowing and simplification, while tergalii II-VII always retain both lamellae, which are widened and have additional processes (in Choroterpes/fg2 each lamella has up to three processes, in Thraulus/g1 - many processes).

In Choroterpes/fg2 the first tergalius is usually unilamellate, very narrow, thread-like, with a single non-branched trachea (Figs 6, 30, 57, 76, 98, 120); rarely wider, with trachea branched (in nigrescens Barnard, 1932 [Choroterpes]); rarely with one process (in Neochoroterpes/g(1) Fig. 66); rarely bilamellate, with both lamellae slender and lacking processes (in petersi Tong et Dudgeon, 2003 [Choroterpes]). Sometimes the first tergalius undergoes further reduction: in prati Puig et Gaino, 1996 [Choroterpes] it is present in male, absent in female; in Dilatognathus subgen.n. it is completely lost.

In Thraulus/g1 the first tergalius usually has both lamellae slender and lacking processes; rarely consists of a single slender lamella lacking processes (in femoratus Li et al., 2006 [Thraulus]). Some species, which are regarded to be related with Thraulus, have the first tergalius bilamellate and similar to tergalii II-VII (hsui Peters et Tsui, 1972 [Thraulus]; mariae Peters et Tsui, 1972 [Thraulus]; torrentis Gillies, 1964 [Masharikella]).
Characters of unclear phylogenetic status.

(2) Larval patella-tibial suture is lost on all legs (Figs 24 $27,46-48,85-87,147-149)$. In contrast to larva, in imago and subimago patella-tibial suture usually retains the primitive condition, being present on middle and hind legs and absent on fore legs; among species examined, only in oklahoma Traver, 1934 [Choroterpes] imago and subimago lack patella-tibial suture on all legs, as in larva.

(3) Hind wing has Sc terminating near middle of costal margin; costal projection is expressed and varies from short and obtuse (Figs 16, 88, 106, 135-137) to stretched and pointed (Figs 40, 50). Larval hind protopteron in all cases has obtuse costal projection; if adult costal projection is stretched and pointed, it grows when wing develops from protopteron (Figs 51, 52).

\section{Plesiomorphy.}

(4) Imaginal and subimaginal claws are always ephemeropteroid.

Classification. The taxon Choroterpes/fg1 is divided into Thraulus/g1 and Choroterpes/fg2. The taxon Thraulus/ g1 [g: Thraulus Eaton 1881: 195] includes taxa known under the generic names Thraulus Eaton, 1881 and Masharikella Peters et al., 1964. Its distribution is limited by the Old World. There are 2 European species: bellus Eaton, 1881 [Thraulus] and thraker Jacob, 1988 [Thraulus]. 3 African species: turbinatus Ulmer, 1909 [Hagenulus]; fasciatus Kimmins, 1956 [Hagenulus]; torrentis Gillies, 1964 [Masharikella]. 11 South Asian species: bishopi Peters et Tsui, 1972 [Thraulus]; demoulini Peters et Tsui, 1973 [Thraulus]; fatuus Kang et Yang, 1994 [Thraulus]; femoratus Li et al., 2006 [Thraulus]; gopalani Grant et Sivaramakrishnan, 1985 [Thraulus]; grandis Gose, 1980 [Thraulus]; macilentus Kang et Yang, 1994 [Thraulus]; mudumalaiensis Soman, 1991 [Thraulus]; semicastanea Gillies, 1951 [Habrophlebiodes]; umbrosus Kang et Yang, 1994 [Thraulus]. Besides this, I have a reared male imago and non-reared imagoes of two undescribed species of Thraulus from Sulawesi. The taxon Choroterpes/fg2 is characterized below.

\subsubsection{Choroterpes/fg2}

Figs 2-151

Systematic position: Choroterpes/fg1-Choroterpes/fg2.

Hierarchical typified name: Choroterpes/fg2 (sine Thraulus; incl. Euthraulus Barnard, 1932).

Possible rank-based names:

- tribus Choroterpini;

- genus Choroterpes.

\section{Autapomorphies.}

(1) Egg surface with a unique relief: there are papillae and ridges; ridges stretch from one papilla to another and form broken lines in such a manner that each papilla is surrounded by a regular crown of several (6-8) acute angles formed by these ridges; usually each such crown is elevated in a form of aster-like or flower-like protuberance (Figs 17, 20-23, 70$75,94,96,97)$. This relief is absent in pacis Sartori, 1991 [Choroterpes] and assimilis Gaino et Sowa, 1985 [Choroterpes (Euthraulus)] [Gattoliat \& Sartori, 2008]. In mercatorius sp.n. [Choroterpes] this relief is modified (Fig. 56).

(2) Each tergalius II-VII has both lamellae wide, 3-pointed, i.e. with two processes by sides of terminal process (Fig. 67, $77-82,140,141)$. Non-unique apomorphy. In selected species some lamellae have less than three apices (Figs 7-12, 31-36, 58-63, 104, 138). In Monophyllus subgen.n. tergalii II-VII are unilamellate (Figs 121-126). Tergalius I has different structure, often thread-like [see Choroterpes/fg1 (1)]. 
(3) Each penis lobe has an apical projection dorsad of gonopore; this projection stretches in distal direction and bears fine colorless denticles. Size of this apical projection varies from very small (e.g., in petersi Tong et Dudgeon, 2003 [Choroterpes]) to very long (Figs 68, 69, 117); its shape varies from rounded (Figs 38, 53, 89) to pointed (Figs 19, 68).

Distribution. Mainly Arctogea (Ethiopian, Oriental, Palaearctic and Nearctic Regions) with a few species in the north of Neotropical Region.

Discussion. During a long time this taxon was confused with Thraulus (see above). Eaton, who described both genera - Choroterpes and Thraulus, distinguished their adults by gonostylus structure: in Thraulus gonostylus has 3 segments ( $1^{\text {st }}$ segment by far the longest, $2^{\text {nd }}$ and $3^{\text {rd }}$ segments short), while for Choroterpes he reported 4 segments: $1^{\text {st }}$ segment short and ring-like, $2^{\text {nd }}$ segment by far the longest (corresponds to $1^{\text {st }}$ segment of Thraulus), $3^{\text {rd }}$ and $4^{\text {th }}$ segments short (correspond to $2^{\text {nd }}$ and $3^{\text {rd }}$ segments of Thraulus) [Eaton, 1881, 1883-1888]. Originally, the genus Choroterpes included a single species Choroterpes lusitanica Eaton, 1881, which later [Eaton, 1883-1888] was synonymized with Choroterpes picteti (Eaton, 1871 [Leptophlebia]). Originally, the name Leptophlebia picteti was introduced for "Potamanthus marginatus Linné" sensu Pictet, 1843-1845 to distinguish it from Leptophlebia marginata (Linnaeus, 1767). Eaton did not see the type specimens and translated description of his Choroterpes picteti from the Pictet's description of Potamantus marginatus. The specimens, on which this description was based, are lost [Kimmins, 1960]. Thus, description of genitals of Choroterpes was based on the type specimens of Choroterpes lusitanica only. Genitals of this species are figured under the name "Choroterpes Picteti" [Eaton, 1883-1888: P1.12, Fig. 19]; on this figure gonostyli are shown as distinctly 4 -segmented, with a ring-like $1^{\text {st }}$ segment. Lectotype of Choroterpes lusitanica was figured by Kimmins [1960: Fig. 45]; on this figure gonostyli are shown as 3segmented, i.e. without separated proximal ring-like " 1 st segment"; this agrees with specimens from Spain examined by me. Gonostylus of Ephemeroptera consists of 4 muscleless secondary segments (which are not homologous to any limb segments of other arthropods); $1^{\text {st }}$ segment is often thicker than $2^{\text {nd }}$ segment; in leptophlebiids, as well as in most other Ephemeroptera, $1^{\text {st }}$ and $2^{\text {nd }}$ segments are fused together without any suture between them, and can be distinguished one from another only by their thickness; $3^{\text {rd }}$ and $4^{\text {th }}$ segments are separated by sutures and have some passive mobility. In Choroterpes picteti $(=C h$. lusitanica $)$ the $1^{\text {st }}$ segment has a transverse impression on lateral side only (Fig. 19), and Eaton wrongly figured this impression as an integral ring-like suture separating the "segments". So, actually Choroterpes and Thraulus have no difference in number of segments of gonostyli: in both taxa gonostyli are 4-segmented with $1^{\text {st }}$ and $2^{\text {nd }}$ segments synsclerotic, so that only 3 segments are movably articulated. Because of this confusion some species of Choroterpes/fg2 were originally placed to Thraulus; the genera Euthraulus Barnard, 1932, Choroterpides Ulmer, 1939 and Thraululus Ulmer, 1939 were originally described as related to Thraulus, as having 3-segmented gonostyli [Barnard, 1932; Ulmer, 1939], while actually they belong to Choroterpes/fg2.

Peters and Edmunds [1964, 1970] suggested that the taxa Choroterpes s.str. and Euthraulus could be separated by furcation of MA (distad the middle of MA in Choroterpes s.str. and at the middle of MA in Euthraulus), furcation of MP (symmetrical in Choroterpes s.str. and asymmetrical in Euthraulus) and shape of costal projection (symmetrically smooth in Choroterpes s.str. and inclined distally in Euthraulus). Actually, no one of these characters agrees with Choroterpes s.str. and Euthraulus determined by larval characters. The species of Choroterpes examined by me, have furcation of MA at the middle and furcation of MP asymmetric (Fig. 15). Shape of costal projection of hind wing highly varies among species, both in Choroterpes s.str. (Figs 16, 40, 50) and Euthraulus (Figs 88, 106).

Bauernfeind [1998] suggested that Choroterpes s.str. and Euthraulus could be separated by shape of median part of styliger, which is concave in Choroterpes s.str. and convex in Euthraulus. However, in Choroterpes (Euthraulus) signatus (Hagen, 1858) styliger varies individually from convex (Fig. 111) to concave (Fig. 115).

Demoulin [1981] keyed larvae of African genus Fulletomimus Demoulin, 1956 as differing from Choroterpes s.l. by a single character - "segments abdominaux à paratergites se terminant par des épines ... doubles (VIII-IX)". However, the same character is found in Choroterpes (Euthraulus) signatus (Hagen, 1858) (Figs 108-109), which has no serrate outer margin of fore wing, characteristic for Fulletomimus. Thus, larva ascribed to Fulletomimus, can belong to Choroterpes/ fg2-Euthraulus/g2.

Classification. The taxon Choroterpes/fg2 is divided into Choroterpes/fg 3 and Euthraulus/g1.

\subsection{Choroterpes/fg3}

Figs 2-67

Systematic position: Choroterpes/fg1-Choroterpes/fg2Choroterpes/fg3.

Hierarchical typified name: Choroterpes/fg3 (sine Euthraulus; incl. Neochoroterpes Allen, 1974).

Possible ranking names:

- genus Choroterpes;

- subgenus Choroterpes.

Autapomorphy.

(1) Middle process of tergalius [one of three apical processes of each two lamella — see Choroterpes/fg2 (2)] is narrow at base and lanceolately widened at middle. This feature can be expressed either on both lamellae (Fig. 67), or on dorsal lamella only (Figs 7-12, 31-36, 58-63); rarely not expressed at all (e.g., in Choroterpes (Neochoroterpes) kossi Allen, 1974 and Ch. (N.) crocatus Allen, 1974).

Plesiomorphy. Unlike Euthraulus/g1, penial arms are not strongly arched and not deeply inserted under the ninth abdominal segment (Figs 19, 38, 53, 65).

Classification. The taxon Choroterpes/fg 3 is divided into plesiomorphon Choroterpes/fg4 and holophyletic taxon Neochoroterpes.

\subsection{Plesiomorphon Choroterpes/fg4} Figs 2-63

Systematic position: Choroterpes/fg1-Choroterpes/fg2Choroterpes/fg 3 - pm.Choroterpes/fg 4 . erpes).

Hierarchical typified name: Choroterpes/fg4 (sine Neochorot-

Possible ranking names:

- genus Choroterpes;

- subgenus Choroterpes.

Plesiomorphy. Labrum retains 2 transverse rows of setae - distal and proximal ones (characteristic for Atalophlebopectinata). The transverse setal row can be either regular (Fig. 43), or irregular (Fig. 28), or represent a stripe of irregularly situated setae (Fig. 13).

Distribution and species composition. Distributed mainly in Arctogea (Ethiopian, Oriental, Palaearctic and Nearctic Regions), with a few species in the north of Neo- 
tropical Region. The following described species belong here for certain: In EUROPE: Ch. picteti picteti (Eaton, 1871 [Leptophlebia]) (=Ch. lusitanica Eaton, 1881); Ch. picteti subcostalis ssp.n.; Ch. borbonica Belfiore, 1988; Ch. prati Puig et Gaino, 1996; Ch. salamannai Gaino et Puig, 1996. In Arabia: Ch. pacis Sartori, 1991 and Ch. ludmilae sp.n.. In NORTHERn AFrica: Ch. atlas Soldán et Thomas, 1983. In South Africa: Ch. nigrescens Barnard, 1932 and Ch. ndebele Agnew, 1962. In Hong Kong: Ch. petersi Tong et Dudgeon, 2003. In Sumatra: Ch. proba Ulmer, 1939. In Sulawesi: Ch. mercatorius sp.n. In North America: $C h$. basalis (Banks, 1900 [Leptophlebia]) $(=$ Ch. ferruginea Traver, 1934, = Ch. fusca Spieth, 1938, = Ch. hubbelli Berner, 1946); Ch. inornata Eaton, 1892 (=Ch. oaxacaensis Brusca et Allen, 1973); Ch. albiannulata McDunnough, 1924; Ch. terratoma Seemann, 1927; Ch. ungulus LugoOrtiz et McCafferty, 1996. In Central America: Ch. gregoryi Ávila et Flowers, 2006 and Ch. mairena Ávila et Flowers, 2006. Besides this, to Choroterpes s.str. are attributed some species described from Europe, Asia and Africa, whose larvae are unknown and systematic position is uncertain. Species examined are reviewed below.

\subsection{1-1. Choroterpes/fg4 picteti [Choroterpes]}

Figs 2-23

Original binomen: Choroterpes picteti Eaton, 1871.

Possible binomina:

- Choroterpes picteti;

- Choroterpes (Choroterpes) picteti.

Larva. Adequately described and illustrated in literature [e.g., Eaton, 1883-1888 (Pl.34); Grandi, 1941].

Cuticular COLORATION: Cuticle nearly colorless, uniformly pale ocher.

Hypodermal Coloration: Head and thorax can have dark brown hypodermal markings; abdomen can have dark brown hypodermal markings as in imago.

SHAPE AND SETATION: Labrum has median emargination very wide, with angulate margins; distal transverse setal row somewhat irregular; proximal transverse setal row wide and irregular (Fig. 13). Mandibles with outer margin very convex (Fig. 14). Medio-apical projection of maxilla differently expressed in two subspecies (Figs 4-5). Femur of fore leg has the same width proximally and at middle, femora of middle and hind legs widest at middle. Stout setae on outer side of femora blunt and pointed,

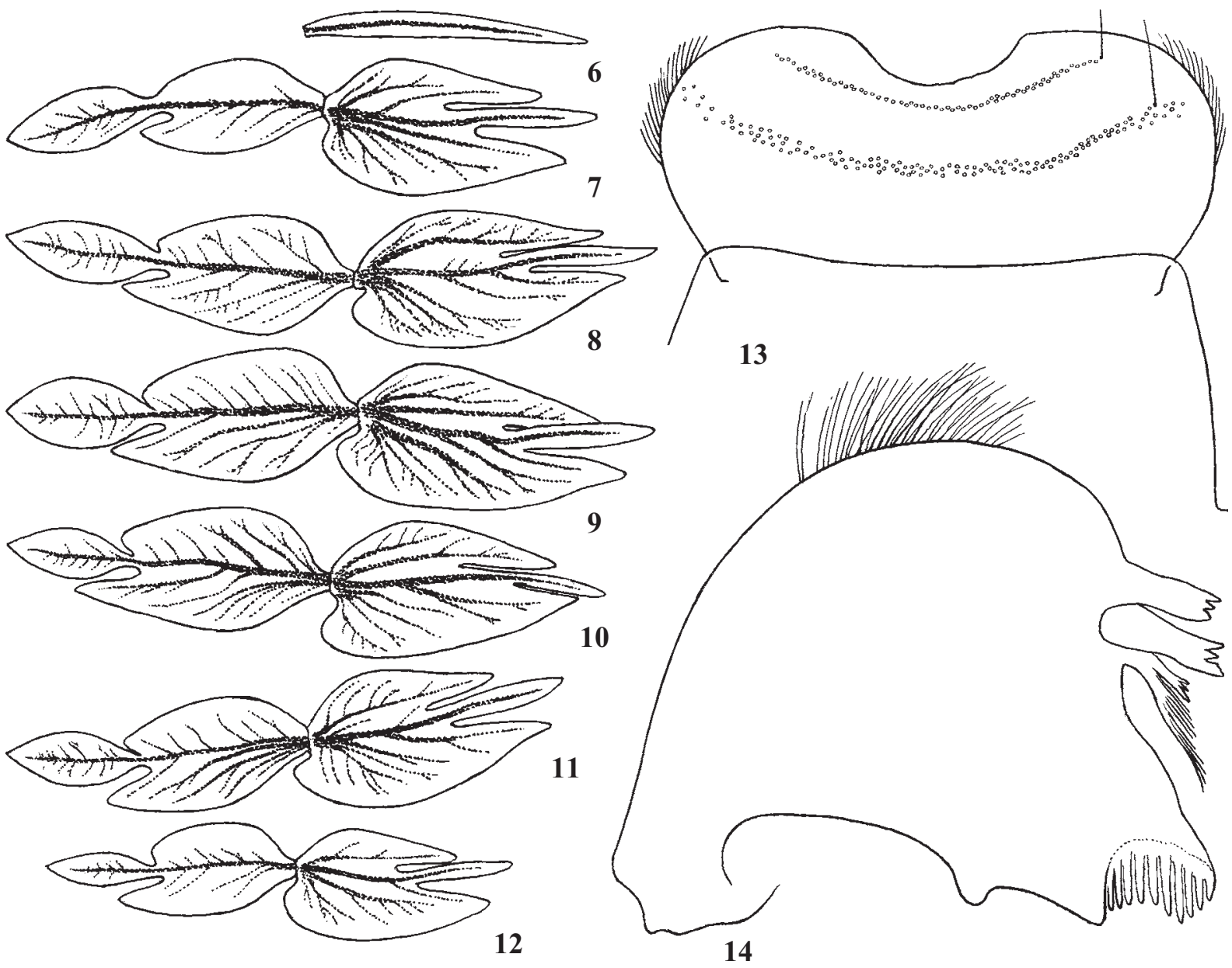

Figs 6-14. Choroterpes (Choroterpes) picteti subcostalis sp.n., larva: 6-12 - tergalii I-VII (dorsal lamella bent to the left); 13 - labrum; dorsal view (instead of setae of distal and proximal transverse rows, only their bases are shown); 14 - left mandible; 6-13 - holotype.

Рис. 6-14. Choroterpes (Choroterpes) picteti subcostalis sp.n., larva: 6-12 - I-VII тергалии (дорсальный листок отогнут влево); 13 - верхняя губа, дорсально (вместо щетинок дистального и проксимального поперечных рядов показаны только их основания); 14 - левая мандибула; 6-13 - голотип. 
short and long, located irregularly. Pectinate setae on ventral side of hind femur pointed and curved, form a stripe parallel to inner margin of femur (similar to Figs 150,151). Stout setae on inner side of fore tibia situated densely and irregularly; each seta pointed, with two rows of stout pointed processes by sides. Middle tibia with very short sparse stout setae irregularly located on inner side only. Hind tibia with sparse stout bipectinate setae, irregularly located on all sides; outer side of hind tibia with blunt setae of variable length, as on outer side of femur [Grandi, 1941: Fig. IX.1, 3, 4]. Outer sides of all tibiae with irregularly situated thin hairs, whose length exceed tibia width. Abdomen without stout setae. Posterolateral spines expressed beginning from abdominal segment II or III. Abdominal tergum I with vestigial denticles on hind margin; terga II-X and segments of caudalii with long pointed denticles on hind margins. Tergalii II-VII [see Choroterpes/fg3 (1)] have all processes developed, except for costal process of dorsal lamella of tergalius II, which can be absent (Figs 7-12). Protopenes of mature male larva short, pressed together, with apices pointed and divergent, completely hidden under sternum XI (Fig. 18). Female larva has hind margin of abdominal sternum IX rounded, without any incision [Grandi, 1941: Fig. X.2].

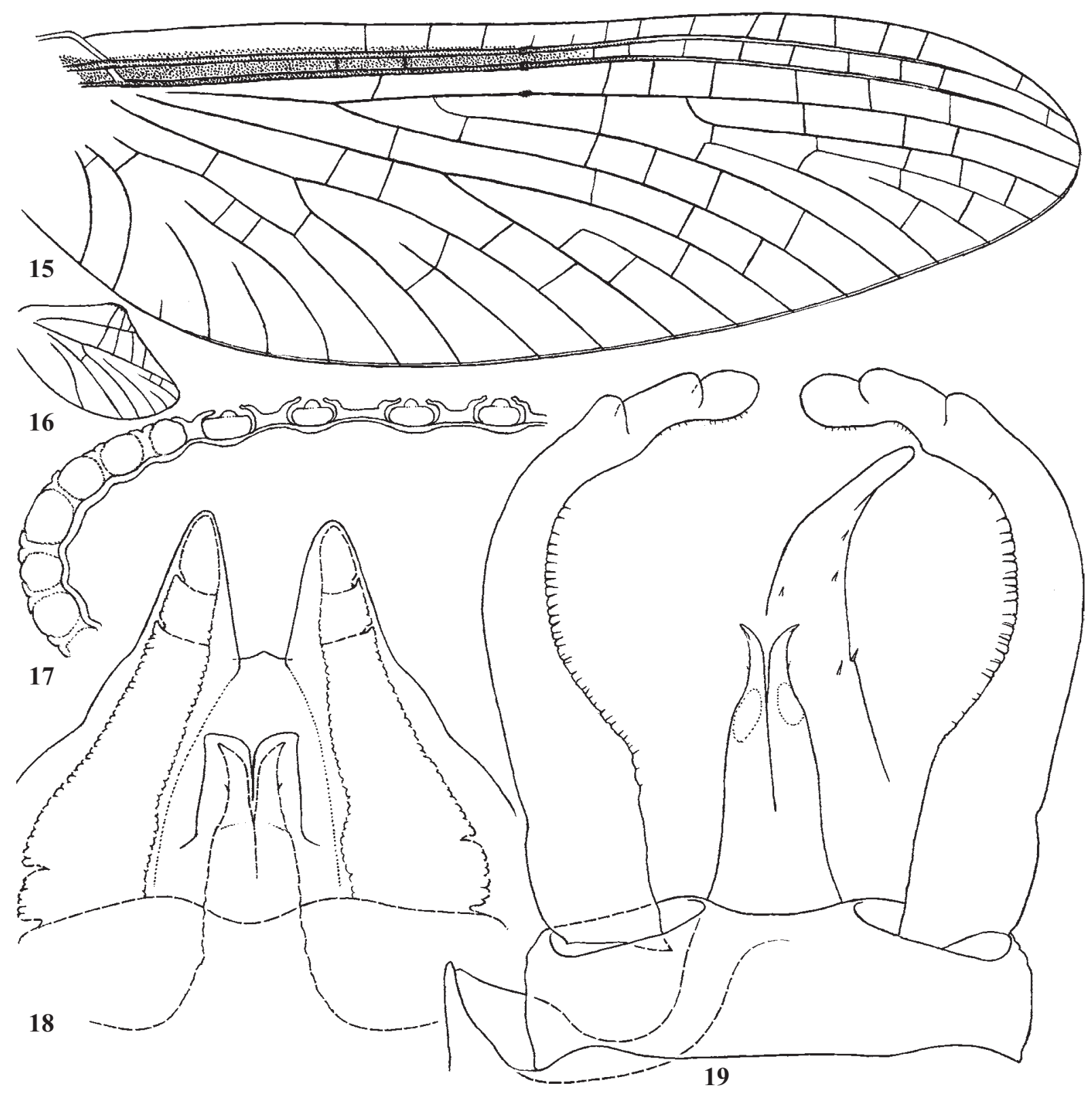

Figs 15-19. Choroterpes (Choroterpes) picteti subcostalis sp.n.: 15-16 - fore and hind wings (holotype); 17 - fragment of optic section of egg surface; 18 - larval protogonostyli and protopenis (dorsal view, shown by integral lines) with developing subimaginal genitals inside (shown by interrupted lines); 19 - genitals of male imago and enlarged apex of right penis (ventral view).

Рис. 15-19. Choroterpes (Choroterpes) picteti subcostalis sp.n.: 15-16 — переднее и заднее крылья (голотип); 17 — участок оптического среза поверхности яйца; 18 - протогоностили и протопенис личинки (дорсально, показаны сплошными линиями) с развивающимися субимагинальными гениталиями внутри (показаны прерывистыми линиями); 19 — гениталии самца имаго и увеличенный правый пенис (вентрально). 
Subimago. Cuticular coloration: Cuticle of thorax at most light; furcasternal protuberances brownish; mesonotum at most brown; most part of medioscutum and submedioscutum brown, posterior scutal protuberance brown except median part (as in Fig. 92). Cuticle of legs light brownish. Wings light brownish. Cuticle of abdomen light brownish, cuticle of gonostyli brown.

Hypodermal coloration: Abdomen with brown maculae as in imago.
TEXTURE: Tarsus of each leg covered by microtrichiae of the same shape as microtrichiae on tibia; only on distal part of $5^{\text {th }}$ tarsomere microtrichiae are gradually substituted by pointed microlepides.

Imago, male. Adequately described and illustrated in literature [e.g., Grandi, 1941]. Head dark brown; dorsal eyes not elevated, brownish-orange. Thorax brown, with membranes ocher. On fore wing at least subcostal area colored with brown in proximal half (in Ch. p. subcostalis - Fig. 15),
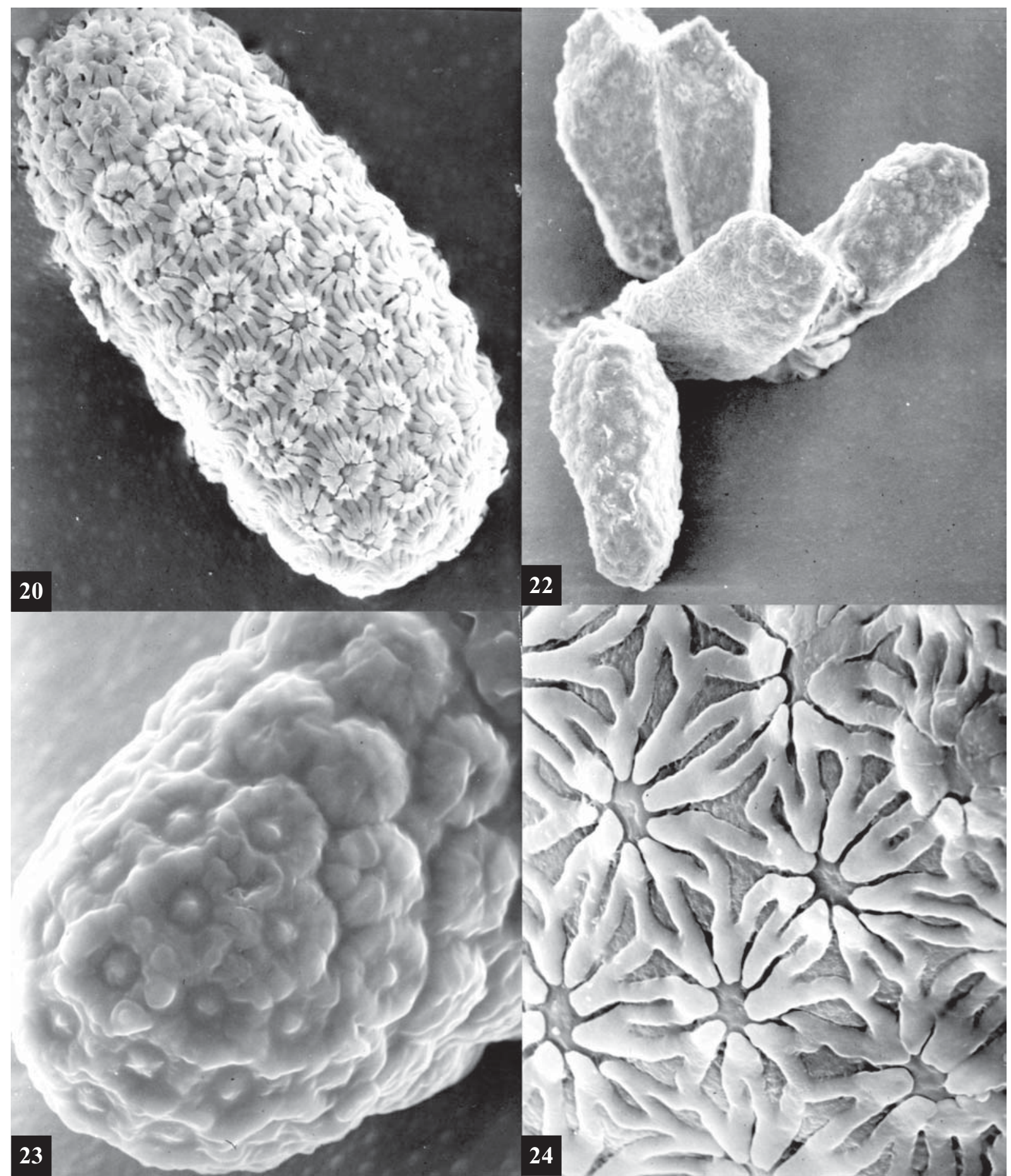

Figs 20-23. Choroterpes (Choroterpes) picteti, eggs: $20-C h$. (Ch.) picteti picteti; 21-23-Ch. (Ch.) picteti subcostalis sp.n. Рис. 20-23. Choroterpes (Choroterpes) picteti, яйца: $20-C h .(C h$.$) picteti picteti; 21-23-Ch. (Ch.) picteti subcostalis sp.n.$ 
or both costal and subcostal areas colored with brown (in. $C h$. p. picteti); pterostigma with about 10 nearly transverse simple crossveins. Hind wing with costal projection blunt (Fig. 16). Femur of each leg brown, darkened at apex; tibia lighter brownish, darkened at base. Abdomen ocher-brownish, each tergum with a pair of large diffusive hypodermal brown maculae widened posteriorly [Grandi, 1941: Fig. XI]. Styliger, gonostyli and penis brown. $1^{\text {st }}+2^{\text {nd }}$ segments of gonostylus with inner margin angulate. Each penis has apical projection [see Choroterpes/fg2 (3)] pointed and bent laterally-ventrally; its denticles are few and small (Fig. 19). Caudalii uniformly brown.

Imago, female. Adequately described and illustrated in literature [e.g., Grandi, 1941]. Coloration as in male. Posterior plate of abdominal sternum IX apically rounded, without incision [Grandi, 1941: Fig. XIX.3].

Egg. Brownish-yellow; relatively narrow, cylindrical. Chorion bears evenly dispersed papillae and ridges going from one papilla to another [see Choroterpes/fg2 (1)]; papillae high, so that each papilla surrounded by overlapping ridge angles, represents a prominent protuberance; in Ch. picteti picteti this relief is the same on the whole egg surface (Fig. 20); in Ch. p. subcostalis ssp.n. one pole differs from the rest surface (Figs 17, 21-23).

DIMENSION. Fore wing length $8 \mathrm{~mm}$.

COMPOSITION. Choroterpes picteti is represented by two subspecies - Ch. picteti picteti and Ch. picteti subcostalis ssp.n.

\subsection{1-1.1. Choroterpes/fg4 picteti picteti [Choroterpes]}

Figs 5, 20

Original binomen: Choroterpes picteti Eaton, 1871.

Possible binomina:

- Choroterpes picteti picteti;

- Choroterpes (Choroterpes) picteti pictetri.

MATERIAL. Imagoes and larvae from Spain, Switzerland, Czech Republic and western Ukraine. River Teterev near Zhitomir, 8.VIII.1928: 7 larvae.

Larva. Adequately described and illustrated in literature [e.g., Eaton, 1883-1888: P1.34; Grandi, 1941]. Medio-apical projection of maxilla not large, less than $1 / 2$ of dentiseta length (Fig. 5).

Imago. Adequately described and illustrated in literature [e.g., Grandi, 1941; Bauernfeind, 1998].

Wing COLOTRATION. On fore wing both costal and subcostal fields entirely colored with brown [Eaton, 1883-1888: P1. 12, Fig. 19; Grandi, 1941: Fig. XI].

Egg. Adequately described and illustrated in literature [Grandi, 1941; Gaino \& Puig, 1996; Haybach, 2003]. Relief characteristic for $C h$. picteti (see above) is the same on all parts of egg (Fig. 20).

DISTRIBUTION. Europe to the east up to Zhitomir Region of Ukraine.

\subsection{1-1.2. Choroterpes/fg4 picteti subcostalis ssp.n. [Choroterpes] \\ Figs 2-4, 6-19, 21-23}

Original binomen: Choroterpes (Choroterpes) picteti subcostalis Kluge, ssp.n.

MATERIAL. Holotype: L-S-I ${ }^{7}$ \{specimen [XIX](7)85\}: RUSSIA, Krasnodar Territory, river Psekups near railway station Goryachiy Kluch, 27.VIII.1985, coll. N. Kluge. Paratypes: the same locality, 26-28.VIII.1985: 5 L-S-I $\sigma^{7}, 2$ L-S $+1 \mathrm{IO}^{7}, 20$ larvae; river Psekups near railway station Fanogoriyskaya, 25-27.VIII.1991, coll. N. Kluge: $1 \mathrm{~L}-\mathrm{S} \sigma^{7}, 1 \mathrm{~S}^{7}, 3$ larvae; river Il', X.1979, coll. E. Kryuchkova: 35 larvae.
Larva. Medio-apical projection of maxilla large, exceeds 1/2 of dentiseta length (Fig. 4).

Imago. Wing COLOTRATION. On fore wing only proximal part of subcostal field colored with brown; costal field nearly colorless (Fig. 15). This coloration is expressed only in imago, but not in subimago and larva: subimaginal fore wing entirely gray; larval fore protopteron either colorless, or with longitudinal brown hypodermal stripe at base of subcostal field; this stripe is not so long as the colored area of imago.

Egg. Chorion with relief characteristic for $C h$. picteti (see above); on one pole papillae are enlarged and brought together (Figs 17, 21-23).

DISTRIBUTION. Known only from western Caucasus.

COMPARISON. Ch. (Ch.) picteti subcostalis ssp.n. differs from $C h$. p . picteti by size of medio-apical projection of larval maxilla, by coloration of imaginal fore wing and by chorion structure of egg.

\subsection{1-2. Choroterpes/fg4 nigrescens [Choroterpes]}

Original binomen: Choroterpes nigrescens Barnard, 1932.

Possible binomina:

- Choroterpes nigrescens;

- Choroterpes (Choroterpes) nigrescens.

REFERENCES: Barnard, 1984: imago and larva; Agnew, 1962: comparison of imago and larva.

MATERIAL. South Africa, Berg river, western Cape, 09.II.1994, coll. F.C. de Moor: 1 male larva.

DISTRIBUTION. South Africa.

\subsection{1-3. Choroterpes/fg4 ludmilae sp.n. [Choroterpes]}

Figs 24-42

Original binomen: Choroterpes (Choroterpes) ludmilae sp.n. MATERIAL. Holotype: L-S-I\# \{specimen [I](1)2010\}: OMAN, Hatta Pools, 28.X.2010, coll. Ludmila Sheyko. Paratypes: the same locality, 2 L/S\#, 1L/S\$, 32 larvae.

Larva. Cuticular COlORATIOn: Head, labrum and exposed parts of mandibles brown; each mandible with roundish diffusive blank. Pronotum brown, with lateral margins colorless. Mesonotum brown. Thoracic pleura partly brown, sterna light. Cuticle of femora with diffusive brown and light areas; tibiae and tarsi brown. Abdomen has terga brown; sterna light, with diffusive brown markings by sides and on styliger. Caudalii brown.

Hypodermal coloration: Head and thorax can have dark brown hypodermal maculation; abdomen and legs with brown maculation as in imago.

SHAPE AND SETATION: Labrum has median emargination shallow, with convexity in middle; distal transverse setal row regular; proximal transverse setal row small and regular or nearly regular (Fig. 28). Mandibles with outer margin moderately convex (similar to Fig. 44). Medio-apical projection of maxilla poorly expressed (Fig. 29). Femur of fore leg widest at proximal part (Fig. 24), femora of middle and hind legs widest at middle (Fig. 27). Stout setae on outer side of femora blunt, vary from short to very long, located irregularly. Pectinate setae on ventral side of hind femur small and ovoid, form a single irregular row parallel to inner margin of femur (Fig. 27). Stout setae on inner side of fore tibia dense and arranged in 3 nearly regular rows (Fig. 25); side processes of these setae either thin and short, or absent. Middle tibia with sparse stout setae irregularly located on inner side only (Fig. 26). Hind tibia with sparse stout non-pectinate setae of variable length, irregularly located on all sides; outer side of hind tibia with blunt setae of variable length, as on outer side of femur. Outer sides 


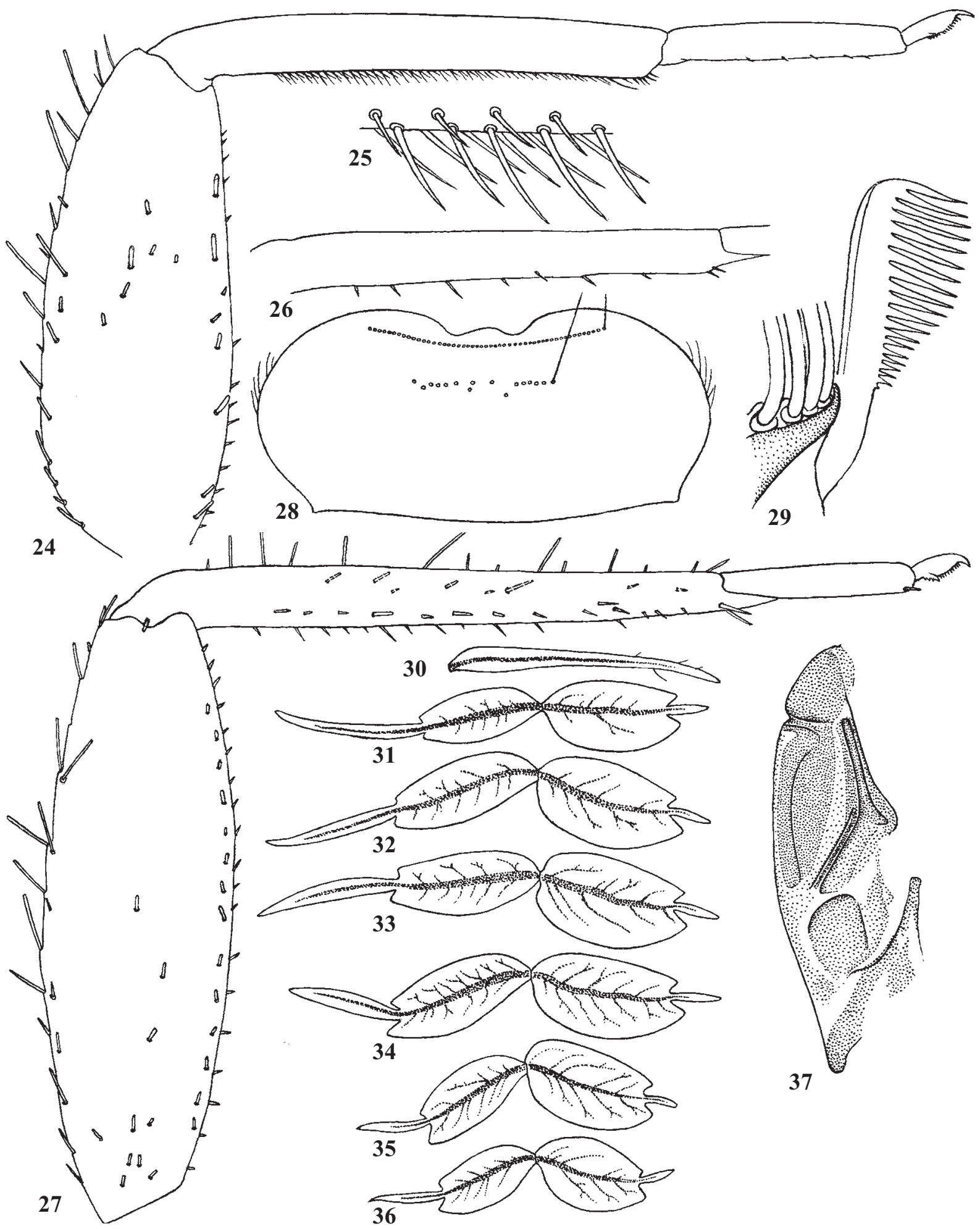

Figs 24-37. Choroterpes (Choroterpes) ludmilae sp.n.: 24-36 - larva: 24 - fore leg (dorsal view); 25 - setae on inner side of fore tibia; 26 - tibia of middle leg; 27 - hind leg (dorsal view); 28 - labrum, dorsal view (instead of setae of distal and proximal transverse rows, only their bases are shown); 29 — medio-apical projection of maxilla, ventral view (dotted); 30-36 — tergalii I-VII (dorsal lamella bent to the left); 37 - exuviae of right half of subimaginal mesonotum; 24-27, 30-37 - holotype.

Рис. 24-37. Choroterpes (Choroterpes) ludmilae sp.n.: 24-36 - личинка: 24 - передняя нога (дорсально); 25 - щетинки на внутренней стороне передней голени; 26 - голень средней ноги; 27 - задняя нога (дорсально); 28 - верхняя губа, дорсально (вместо щетинок дистального и проксимального поперечных рядов показаны только их основания); 29 - медио-апикальный выступ максиллы, вентрально (пунктирован); 30-36 - I-VII тергалии (дорсальный листок отогнут влево); 37 — экзувий правой половины субимагинального мезонотума; 24-27, 30-37 - голотип. 

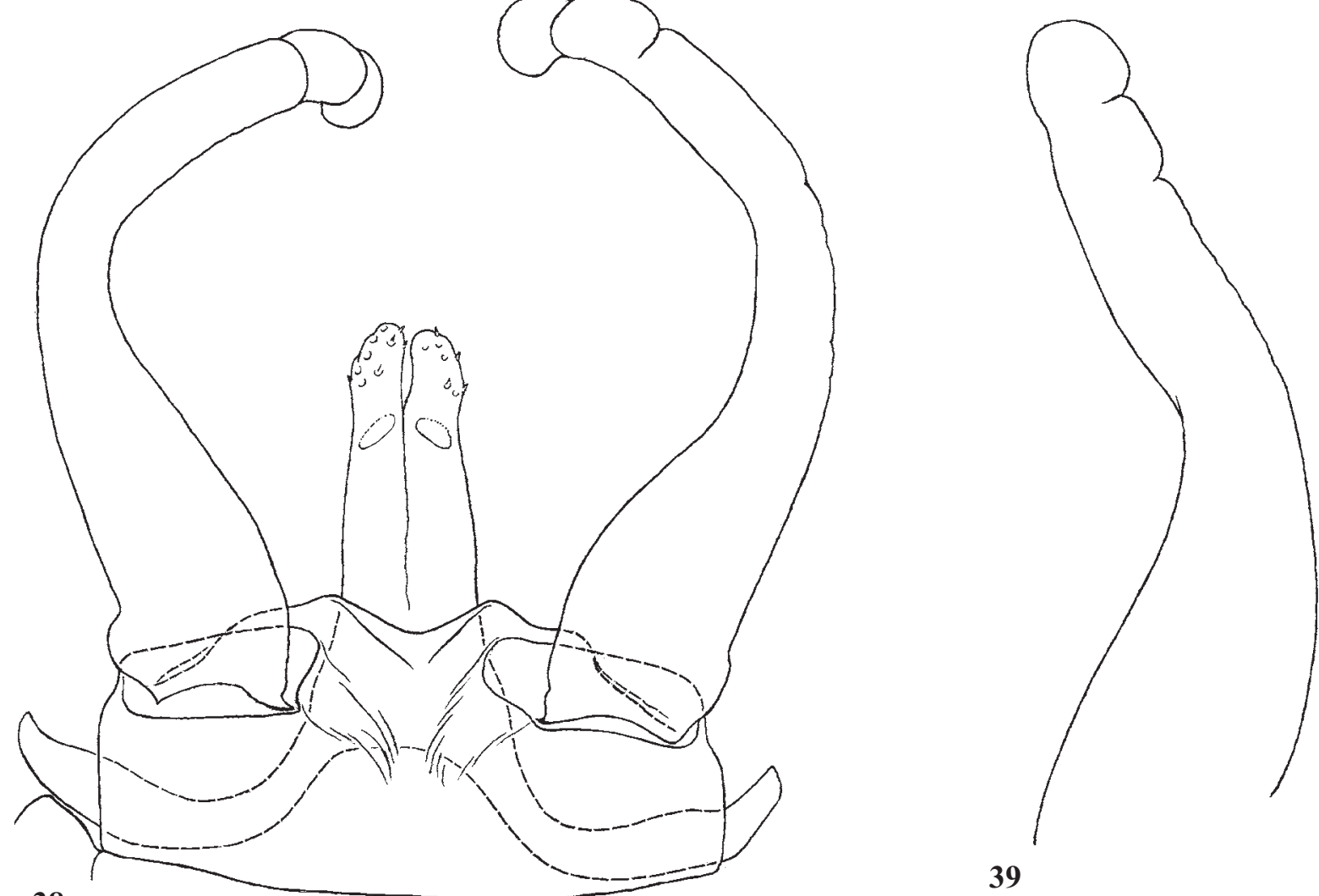

38

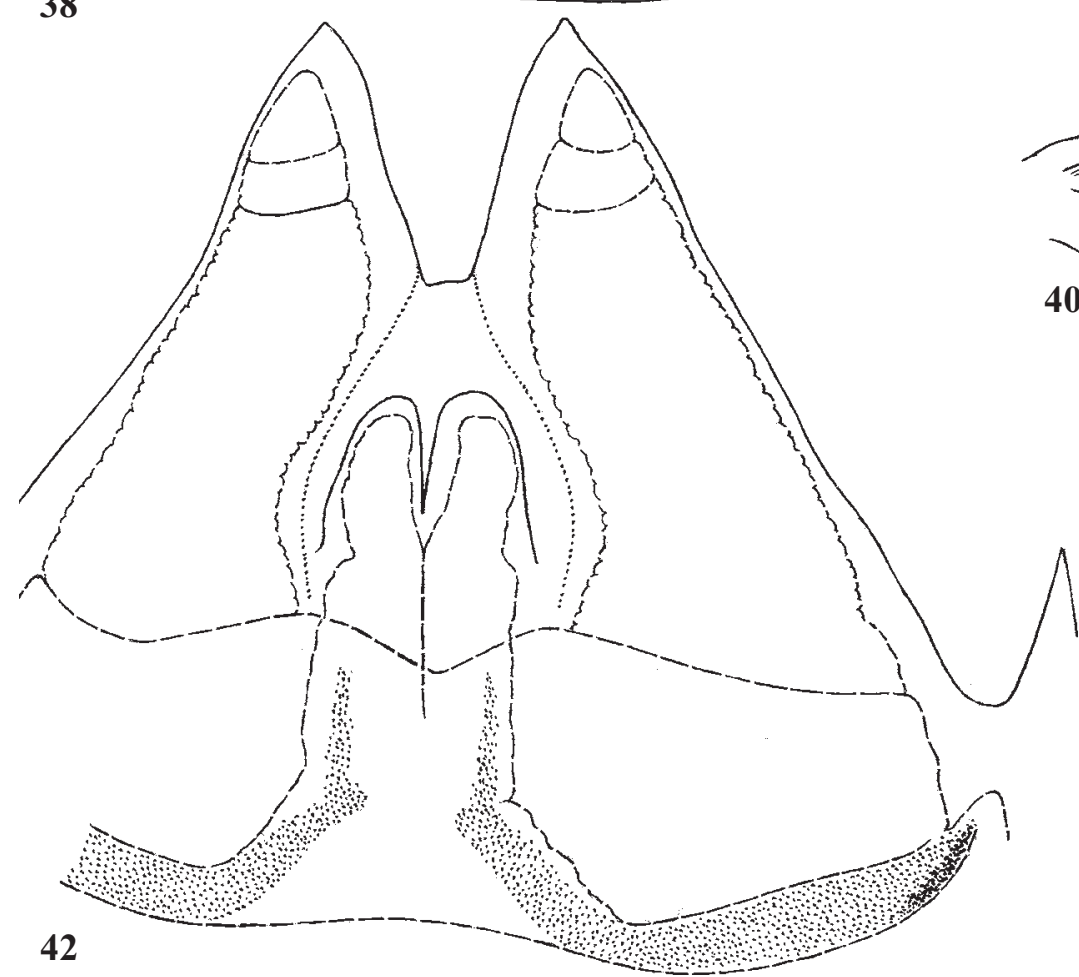

39

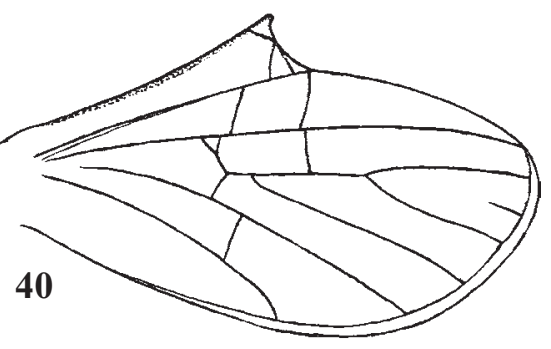

Figs 38-42. Choroterpes (Choroterpes) ludmilae sp.n.: 38 - genitals of male imago, ventral view; 39 - gonostylus of subimago; 40 - hind wing; 41 - tergum VI of abdomen of male imago; 42 - larval protogonostyli and protopenis (dorsal view, shown by integral lines) with developing subimaginal genitals inside (shown by interrupted lines); 38-41 - holotype.

Рис. 38-42. Choroterpes (Choroterpes) ludmilae sp.n.: 38 - гениталии самца имаго, вентрально; 39 - гоностиль субимаго; 40 заднее крыло; 41 - VI тергит брюшка самца имаго; 42 - протогоностили и протопенис личинки (дорсально, показаны сплошными линиями) с развивающимися субимагинальными гениталиями внутри (показаны прерывистыми линиями); 38-41 — голотип. 
of all tibiae with irregularly situated thin hairs, whose length exceed tibia width (not shown in Figs 24-27). Abdomen without stout setae. Posterolateral spines expressed beginning from abdominal segment V or VI. Abdominal tergum I with vestigial denticles on hind margin; terga II-IX with small triangular denticles - either equilateral or longer; tergum $\mathrm{X}$ and each segment of caudalii with longer denticles; sterna without denticles. Tergalii II-VII [see Choroterpes/fg3 (1)] have simplified structure: ventral lamella has side processes very short, median process diminished; dorsal lamella has side processes extremely short, median process narrow (Figs 3136). Protogonostyli of male larva nearly contiguous at base; protopenes short, divergent, completely hidden under sternum XI (Fig. 42). Female larva has hind margin of abdominal sternum IX deeply incised (as in Fig. 54).

Subimago. Cuticular coloration: Cuticle of thorax at most light, mesonotum at most brown: most part of medioscutum and submedioscutum brown, posterior scutal protuberance brown except median part (Fig. 37). Cuticle of legs colorless. Wings light brownish. Cuticle of abdomen colorless, cuticle of gonostyli brown.

HYPODERMAL COLORATION: Legs and abdomen with brown maculation as in imago.

TEXTURE: On each leg $1^{\text {st }}$ tarsomere (shortened and fused with tibia) covered by microtrichiae of the same shape as microtrichiae on tibia; $2^{\text {nd }}-5^{\text {th }}$ tarsomeres covered by pointed microlepides.

Imago, male. Head dark brown; dorsal eyes not elevated [as in Kluge, 1984: Fig. 22], brownish-orange. Thorax dark brown, with membranes whitish. On fore wing basal sclerites brownish, veins and membrane colorless; pterostigma whitish, with 6-7 simple oblique crossveins. Hind wing with costal process stretched, pointed and inclined distally (Fig. 40). Femur of each leg light, with dark brown hypodermal macula near apex and diffusive hypodermal macula at middle; on middle and hind legs this middle macula is nearly absent. Tibia of each leg at most colorless, with light brown cuticular pigment at base. Abdominal terga II-IX with repeated dark brown hypodermal ornament on colorless background (Fig. 41); sterna colorless. Gonostyli colorless, penis light brownish. $1^{\text {st }}+2^{\text {nd }}$ segments of gonostylus with inner margin nonangulate. Each penis has apical projection [see Choroterpes/ fg2 (3)] not long, bent medially, with apex roundish; its denticles are small, directed distally (Fig. 38). Caudalii light, at proximal part of each caudalius, articulations of segments with contrasting hypodermal dark brown coloration.

Imago, female. Unknown.

Egg. Unknown.

DIMENSION. Fore wing length $4 \mathrm{~mm}$.

DISTRIBUTION. Known from a single point in Oman.

COMPARISON. Ch. ludmilae sp.n. is similar to $C h$. pacis Sartori, 1991, which was originally described as male imagoes from Oman [Sartori, 1991] and redescribed by Gattolliat \& Sartori (2008) based on larvae and subimagoes collected in United Arab Emirats and presumably attributed to this specie. Imago of $C h$. ludmilae sp.n. differs from $C h$. pacis by sharp costal projection of hind wing, coloration of male imaginal abdomen and absence of dark longitudinal stripes on legs. Among Choroterpes s.str., besides Ch. ludmilae sp.n., sharp costal projection occurs in Ch. petersi Tong \& Dudgeon, 2003 and Ch. mercatorius sp.n.; both species differ from Ch. ludmilae sp.n. by angulate inner margin of gonostyli and different shape of penis.

ETYMOLOGY. The species is named in honor of Ludmila Sheyko, my wife, who is the first to rear mayfly imago from larva in Arabian Peninsula.

\subsection{1-4. Choroterpes/fg4 mercatorius sp.n. [Choroterpes] Figs 43-63}

Original binomen: Choroterpes (Choroterpes) mercatorius sp.n. MATERIAL. Holotype: L-S-I $\sigma^{7}\{$ specimen [XXI](7) $\}$ : INDONESIA, Sulawesi Island, Pinrang 31.VIII.2009, coll. N. Kluge \& L. Sheyko. Paratypes: the same locality, 28-31.VIII.2009: 1 L-S-I,+ 2 L$\mathrm{S} \sigma^{7}, 1 \mathrm{~L}-\mathrm{S}+, 1 \mathrm{~S}-\mathrm{IO}^{7}, 1 \mathrm{~S}+, 7$ larvae.

Larva. Cuticular COlORATion: Cuticle of head, thorax, legs and abdomen either colorless, or with diffusive light brownish markings.

HyPoDERMal coloration: Head and thorax can have dark brown hypodermal maculation; abdomen with brown maculation as in imago.

SHAPE AND SETATION: Labrum has median emargination shallow, with vestigial blunt denticles; distal transverse setal row regular; proximal transverse setal row small and regular (Fig. 43). Mandibles with outer margin moderately convex (Fig. 44). Medio-apical projection of maxilla poorly expressed (as in Fig. 29). Femur of fore leg has the same width proximally and at middle (Fig. 46), femora of middle and hind legs widest at middle (similar to Fig. 27). Femora with irregularly situated stout setae of various length and shape - blunt and pointed, pectinate and smooth. Pectinate setae on ventral side of hind femur pointed and curved, form a stripe parallel to inner margin of femur (similar to Figs 150-151). Stout setae on inner side of fore tibia situated densely and irregularly, bipectinate (pointed, with two rows of stout pointed processes by sides). Inner side of middle tibia with a row of stout setae, which are longer than setae on inner sides of fore and hind tibiae (Fig. 47). Hind tibia with sparse stout bipectinate and non-bipectinate setae, irregularly located on all sides; outer side of hind tibia with stout setae of variable length, as on outer side of femur (Fig. 48). Outer sides of all tibiae with irregularly situated thin hairs, whose length exceed tibia width (not shown in Figs 46-48). Each abdominal segment IV-IX with a row of stout blunt setae on each lateral margin (Fig. 55). Posterolateral spines expressed beginning from abdominal segment $\mathrm{V}$. Abdominal tergum I without denticles on hind margin; terga II-IX with small triangular pointed denticles; tergum $\mathrm{X}$ and each segment of caudalii with longer denticles; sterna without denticles. Tergalii II-VII [see Choroterpes/fg3 (1)] have costal process of dorsal lamella reduced: on tergalius II it is absent, on tergalii II-VII absent or very small; other processes well developed (Figs 58-63). Protogonostyli of male larva nearly contiguous at base; protopenes very short, convergent, completely hidden under sternum XI (Fig. 55). Female larva has hind margin of abdominal sternum IX deeply incised (Fig. 54).

Subimago. Cuticular COlORATION: Cuticle of thorax at most light; mesonotum at most light brownish, only sutures (anteronotal transverse impression, anterolateral scutal costa, antelateroparapsidal and lateroparapsidal sutures) darker brown. Cuticle of legs colorless. Wings light brownish. Cuticle of abdomen colorless, cuticle of gonostyli light brownish.

HYPODERMAL COLORATION: Abdomen with brown maculation as in imago.

Texture: On each leg $1^{\text {st }}$ tarsomere (shortened and fused with tibia) covered by microtrichiae of the same shape as microtrichiae on tibia; $2^{\text {nd }}-5^{\text {th }}$ tarsomeres covered by pointed microlepides.

Imago, male. Head brown; dorsal eyes not elevated [as in Kluge, 1984: Fig.22], brownish-orange. Thorax brown with ocher. On fore wing basal sclerites brownish, veins light, membrane colorless; pterostigma whitish, with 6-8 simple oblique crossveins. Hind wing with costal process stretched, pointed and inclined distally (Fig. 50). Legs light; on each leg 
cuticle of knee area (apex of femur and base of tibia) colored by light brown; hypodermal coloration similar to that of female (see below), but poorly developed. Abdominal terga II-IX with repeated dark brown hypodermal ornament on colorless background (Fig. 49); sterna colorless. Gonostyli light brownish, penis lighter. $1^{\text {st }}+2^{\text {nd }}$ segments of gonostylus with inner margin angulate. Penes short; each penis has apical projection [see Choroterpes/fg2 (3)] not long, bent laterally, with apex roundish; its denticles are well developed and directed distally (Fig. 53). Caudalii light.
Imago, female. Head and thorax brown with ocher. Legs with cuticular coloration as in male; femora with dark brown hypodermal maculation: band near apex of fore, middle and hind femur and longitudinal stripe at middle of hind femur. Abdomen ocher with brown hypodermal ornament as in male. Posterior plate of abdominal sternum IX apically deeply incised (as in larva - Fig. 54).

Egg. White, without any pigmentation; long and narrow. Chorion has unique relief: papillae surrounded by crowns of broken ridges [see Choroterpes/fg2 (1)] are located only on

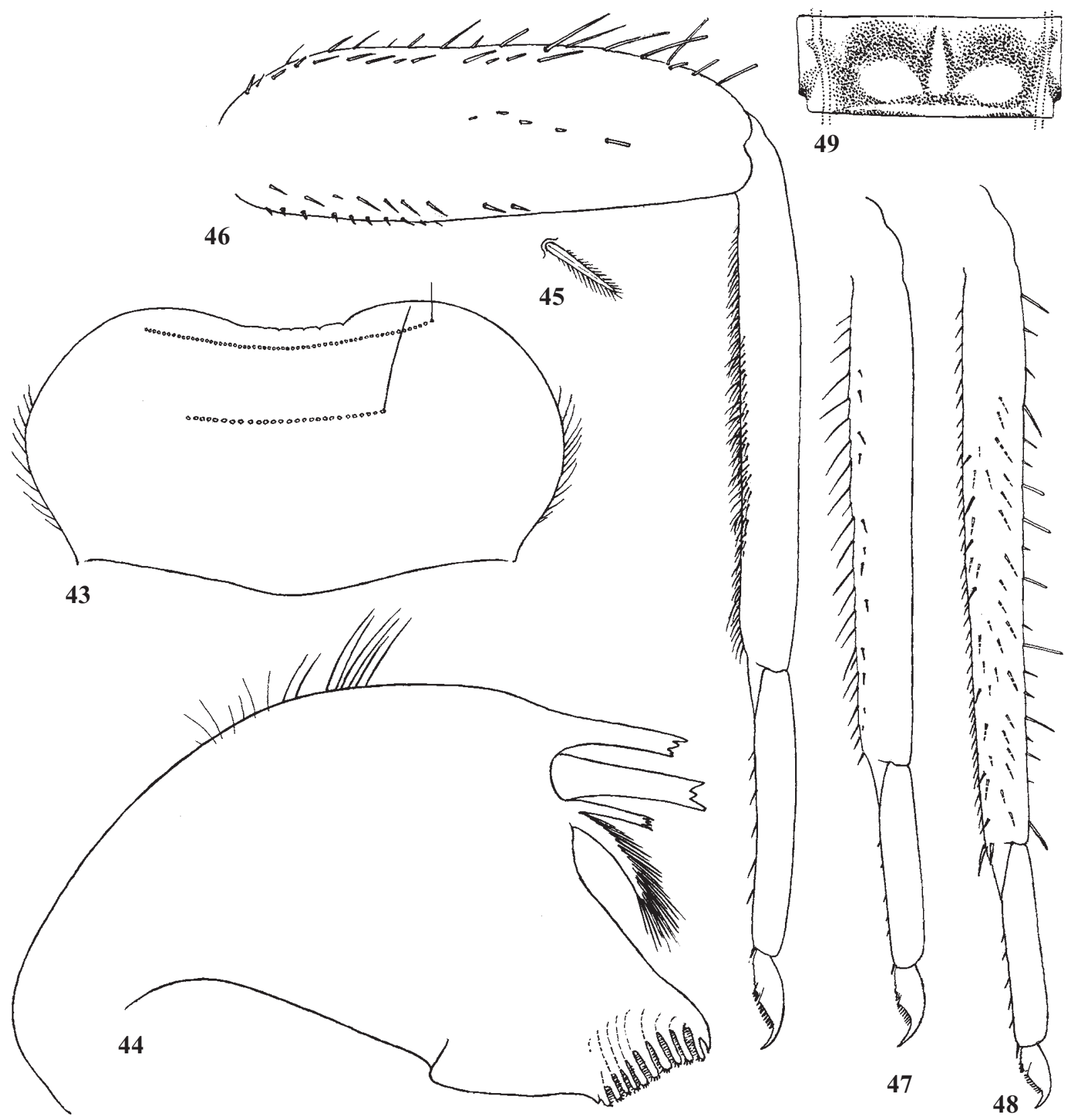

Figs 43-49. Choroterpes (Choroterpes) mercatorius sp.n.: 43-48 - larva: 43 - labrum, dorsal view (instead of setae of distal and proximal transverse rows, only their bases are shown); 44 - left mandible; 45 — seta on inner side of fore femur; 46 - fore leg (dorsal view); 47 — tibia and tarsus of middle leg; 48 - tibia and tarsus of hind leg; 49 - tergum VI of abdomen of male imago; 45-49 - holotype.

Рис. 43-49. Choroterpes (Choroterpes) mercatorius sp.n.: 43-48 - личинка: 43 - верхняя губа, дорсально (вместо щетинок дистального и проксимального поперечных рядов показаны только их основания); 44 — левая мандибула; 45 — щетинка на внутренней стороне переднего бедра; 46 — передняя нога (дорсально); 47 — голень и лапка средней ноги; 48 — голень и лапка задней ноги; 49 - VI тергит брюшка самца имаго; $45-49$ - голотип. 


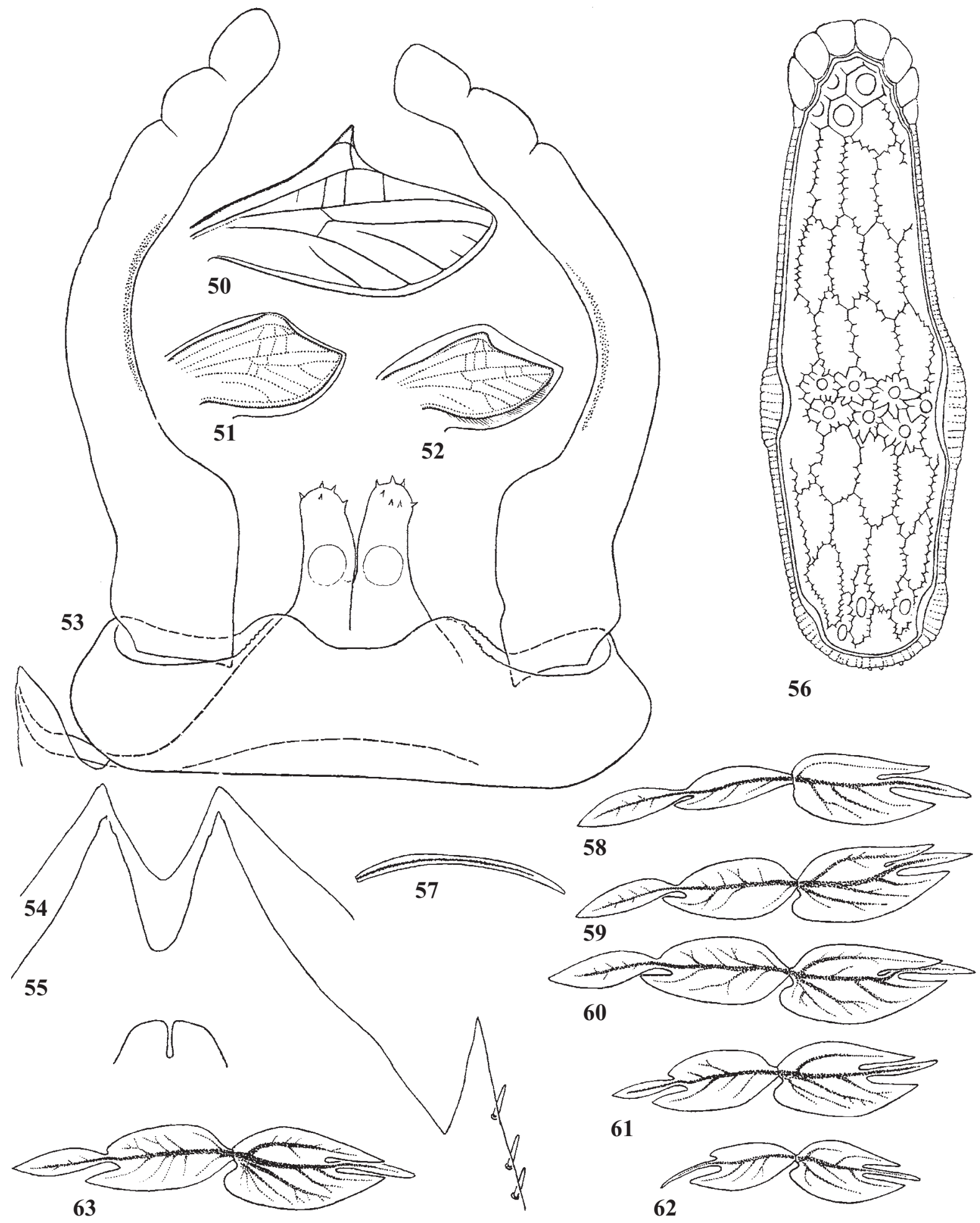

Figs 50-63. Choroterpes (Choroterpes) mercatorius sp.n.: 50 - hind wing of imago; 51-52 - hind protopteron of larva with developing wing inside; 53 - genitals of male imago, ventral view; 54 - outline of hind margin of abdominal sternum IX of mature female larva; 55 — hind part of abdominal sternum IX of mature male larva with protogonostyli and protopenis (dorsal view); 56 - egg (in middle — surface view, in periphery - optic section); 57-63 - tergalii I-VII (dorsal lamella bent to the left); 50, 53, 57-63 - holotype.

Рис. 50-63. Choroterpes (Choroterpes) mercatorius sp.n.: 50 - заднее крыло имаго; 51-52 - задний протоптерон личинки с развивающимся задним крылом внутри; 53 - гениталии самца имаго, вентрально; 54 - очертание заднего края IX стернита брюшка зрелой личинки самки; 55 - задняя часть IX стернита брюшка зрелой личинки самца с протогоностилями и протопенисом (дорсально); 56 - яйцо (в середине - вид поверхности, по периферии - оптический срез); 57-63 - I-VII тергалии (дорсальный листок отогнут влево); 50, 53, 57-63 - голотип. 
poles and equator; on one pole papillae are very large and pressed together with ridges; on another pole and on equator papillae have moderate size, each being surrounded by a crown of broken ridges; areas between each pole and equator are filled with crowns of broken ridges stretched in longitudinal direction (Fig. 56).

DIMENSION. Fore wing length $5 \mathrm{~mm}$.

DISTRIBUTION. Sulawesi.

COMPARISON. Among Choroterpes s.str., besides $C h$. mercatorius sp.n., sharp costal projection occurs in $C h$. ludmilae sp.n. and Ch. petersi Tong \& Dudgeon, 2003; both species differ from Ch. mercatorius sp.n. by longer penis. Larva differs from other examined species of Choroterpes s.l. by the following characters: stout setae on inner side of middle tibia are longer than setae on inner sides of fore and hind tibiae; abdomen with stout setae on lateral margin.

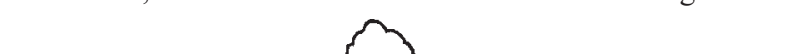

ETYMOLOGY. The species was collected in a street market located on banks of a canal in the town of Pinrang.

\subsection{Neochoroterpes/g(1), or Neochoroterpes} Figs 64-67

Systematic position: Choroterpes/fg1-Choroterpes/fg2Choroterpes/fg3-Neochoroterpes.

Hierarchical typified name: Neochoroterpes/g1 [g: Neochoroterpes Allen, 1974; type species: Choroterpes (Neochoroterpes) mexicanus Allen, 1984].

Possible rank-based names:

- genus Neochoroterpes;

- subgenus Neochoroterpes in genus Choroterpes.

Autapomorphy.

(1) Labrum lost transverse setal rows characteristic for Atalophlebopectinata: instead of distal row it has a wide field of irregularly situated setae, instead of proximal row it has a

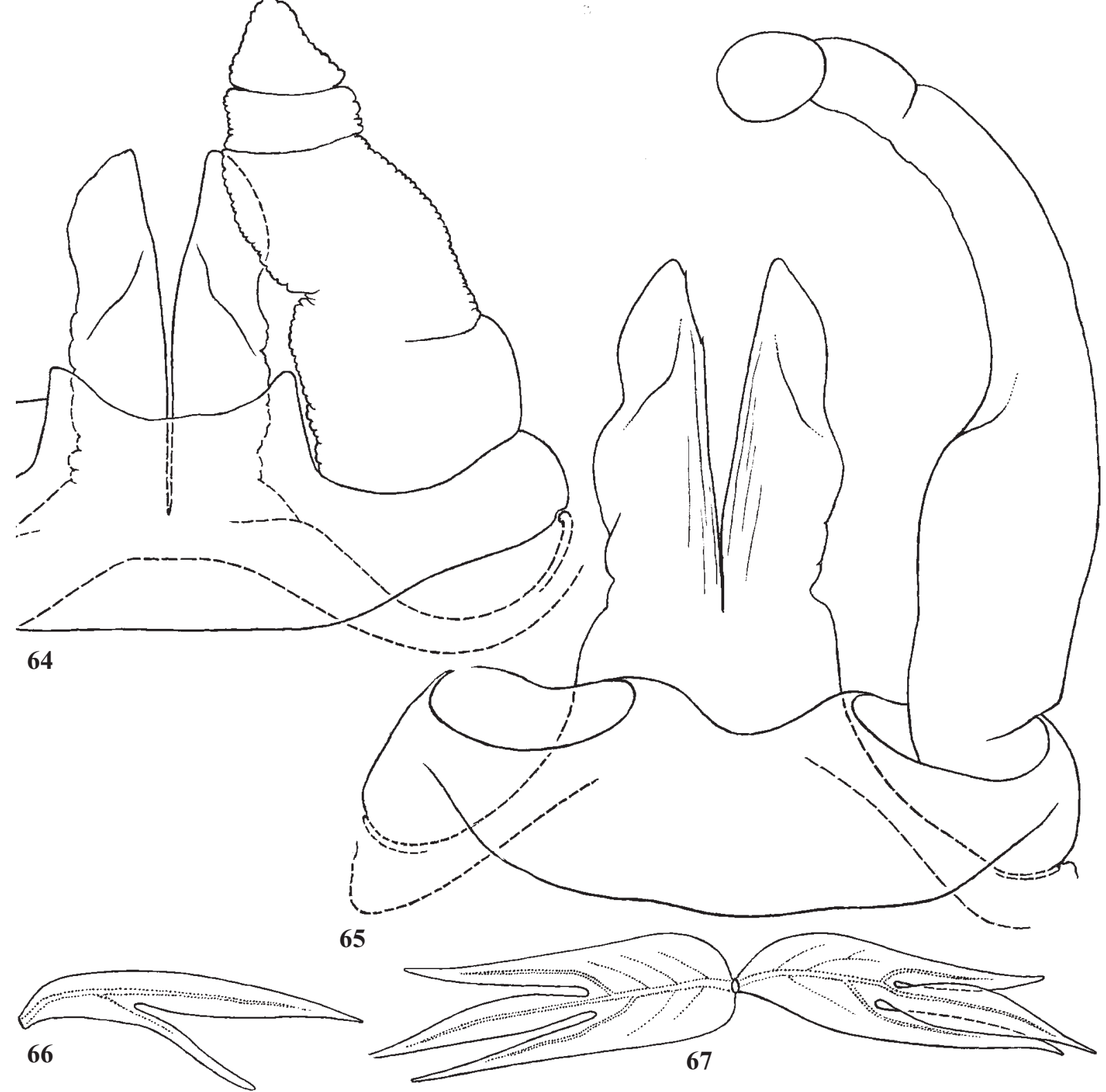

Figs 64-67. Choroterpes (Neochoroterpes) oklahoma: 64 - crumpled genitals of male subimago, extracted from larva (ventral view); 65 - genitals of male imago (ventral view); 66, 67 - tergalii I and IV.

Рис. 64-67. Choroterpes (Neochoroterpes) oklahoma: 64 - смятые гениталии самца субимаго, отпрепарированные из личинки (вентрально); 65 - гениталии самца имаго (вентрально); 66, 67 - I и IV тергалии. 
larger field of irregularly situated longer setae [Henry, 1993: Figs 1-4].

Distribution and species composition. Distributed in New World, mainly in southern part of North America. 6 species are formally described: nanita Traver, 1934 [Choroterpes], oklahoma Traver, 1934 [Choroterpes], mexicanus Allen, 1974 [Choroterpes (Neochoroterpes)], crocatus Allen, 1974 [Choroterpes (Neochoroterpes)], kossi Allen, 1974 [Choroterpes (Neochoroterpes)] and orientalis Henry, 1993 [Neochoroterpes]. Among them, crocatus [Choroterpes] is regarded to be a junior synonym of nanita [Choroterpes] [Henry, 1993]. The same author regarded mexicanus [Choroterpes] to be a junior synonym of oklahoma [Choroterpes] [Henry, 1993]. However, subimaginal penis of mexicanus [Choroterpes], figured in the original description [Allen, 1974: Figs 4-5] is very short and triangular, similar to penis of nanita [Choroterpes] [Traver, 1934: Fig. 2; Henry, 1993: Fig. 25]; in contrast to this, penis of oklahoma [Choroterpes] is much longer, with widened apices, being the same in imago and subimago (Figs 64-65).

\subsection{2-1. Neochoroterpes/g(1) oklahoma [Choroterpes]}

Figs 64-67

Original binomen: Choroterpes oklahoma Traver, 1934. Possible binomina:

- Neochoroterpes oklahoma;

- Choroterpes (Neochoroterpes) oklahoma.

REFERENCES: Traver, 1934: imago; Henry, 1993: imago and larva.

MATERIAL. USA, Texas, Runnels Co., Rd3115, Colorado River, 15.III.1993, B. Kondratieff: $11 \mathrm{I}^{7}, 1 \mathrm{I}$ I $, 1 \mathrm{~L} / \mathrm{S} \sigma^{\prime}, 2 \mathrm{~L} / \mathrm{S}$ ㅇ.

DISTRIBUTION. Southern Nearctic.

\subsection{Euthraulus/g1}

Figs 68-151

Systematic position: Choroterpes/fg1-Choroterpes/fg2-Euthraulus/g1.

Hierarchical typified name: Euthraulus/g1 (incl. Monophyllus, Dilatognathus) [g: Euthraulus Barnard, 1932; type species: E. elegans Barnard, 1932].

Possible rank-based names:

- genus Euthraulus;

- subgenus Euthraulus in genus Choroterpes.

Autapomorphy.

(1) Penial arms are strongly arched and dipped into abdominal segment IX far anteriad of transverse sterno-styligeral impression (Figs 68-89, 111-112, 114-115, 117, 145).

Classification. The taxon Euthraulus/g1 is divided into plesiomorphon Euthraulus/g2 and holophyletic taxa Monophyllus/g(1) and Dilatognathus/g(1).

\subsection{Plesiomorphon Euthraulus/g2} Figs 68-116

Systematic position: Choroterpes/fg1-Choroterpes/fg2-Euthraulus/g1—pm.Euthraulus/g2 .

Hierarchical name: Euthraulus/g2 (sine Monophyllus, Dilatognathus).

Possible rank-based names:

— genus Euthraulus;

- subgenus Euthraulus.

Character of unclear phylogenetic status.

(1) Tergalii II-VII are bilamellate (unlike Monophyllus); at each lamella all three apical processes [see Choroterpes/ fg2 (2)] are subequal, long and slender (unlike Dilatognath$u s$ ) (Figs 77-82, 99-105).

Discussion. The name Thraululus Ulmer, 1939 is regarded to be a junior synonym of Euthraulus [Gillies, 1957].
However, larva of the type species of Thraululus (marginatus Ulmer, 1913 [Thraulus]) is unknown, so this species cannot be identified as belonging to Euthraulus for certain.

Distribution and species composition. Distributed in Old World (Ethiopian, Oriental and Palaearctic Regions). The following described species belong here for certain: In WEST PALAEARCTIC: assimilis Gaino et Sowa, 1985 [Choroterpes (Euthraulus)](Greece); balcanicus Ikonomov, 1961 [Euthraulus] (Macedonia); ortali Sartori, 1992 [Choroterpes (Euthraulus)] (Israel); caucasicus sp.n. [Choroterpes (Euthraulus)] (Russian Caucasus); sumbarensis Kluge, 1984 [Choroterpes (Euthraulus)] (Turkmenistan); arabica Sartori et Gillies, 1990 [Choroterpes (Euthraulus)] (Saudi Arabia); lindrothi Peters, 1980 [Choroterpes] (= mauritanicus Soldán et Thomas, 1983 [Choroterpes (Euthraulus)]) (northern Africa). In EAST PALAEARCTIC: quadricus Ali, 1967 [Choroterpes] (Pakistan); altioculus Kluge, 1984 [Choroterpes (Euthraulus)] (East Siberia and Far East); anhuensis Wu et You, 1992 [Choroterpes] (China). In ORIENTAL REGION: alagarensis Dinakaran et al., 2009 [Choroterpes] (India); signata Hagen, 1858 [Cloe] (Sri Lanka); nanjingensis You et al., 1979 [Choroterpes (Euthraulus)] (China); taiwanensis Kang et Yang, 1994 [Choroterpes] (Taiwan); trifurcatus Ueno, 1928 [Choroterpes] (Taiwan); vittata Nguyen et Bae, 2003 [Choroterpes] (Vietnam). In ETHIOPIAN REGION: bugandensis Kimmins, 1956 [Euthraulus]; elegans Barnard, 1932 [Euthraulus]; starmuehlneri Peters, 1980 [Choroterpes (Euthraulus)]; usambarae Gillies, 1957 [Euthraulus]. Species examined are reviewed below.

\subsection{1-1. Euthraulus/g2 altioculus [Choroterpes]} Figs 68, 70-73

Original binomen: Choroterpes (Euthraulus) altioculus Kluge, 1984.

Possible binomina:

- Choroterpes (Euthraulus) altioculus;

- Euthraulus altioculus.

REFERENCES: Kluge, 1984: male imago and larva.

MATERIAL. Holotype and paratypes [Kluge, 1984]: Primorskiy Kray, natural reserve "Kedrovaya Pad"”, river Barabashevka (= Mongugay), 24.VI-10.VII.1980, coll. N. Kluge: 1 L-S-IO' (holotype), 10 larvae; ibid., river Narva (= Sidime), 14-26.VII.1981, coll. N. Kluge: 1 L-S-I ${ }^{7}, 1$ L-S-I ${ }^{\circ}, 8$ larvae; natural reserve Lazovskiy, river Kievka, 16-20.VIII.1981, coll. N. Kluge: 3 larvae; river Ussuri near Novo-Chuguevka, 25.VIII.1980, coll. No. Kluge: 1 L-S-Iㅇ.

Bauernfeind [1998] erroneously reported that holotype is "männchen Imago", while actually it represents larval, subimaginal and imaginal stages of the male specimen.

OTHER MATERIAL: RUSSIAN FEDERATION: Tomsk Province, river Mrassu near Tomsk, 16.VIII.1940, coll. V. Kruglova: 3 young larvae. Altai, Teletskoe Lake, 25.VI.1951, Yu. Zasypkina: 1 $\mathrm{I}(\mathrm{m})$. Kemerovo Province (Kuzbass): river Kaitan above village Sarbain, 29.VII.1949, coll. B. Rohdendorf: 1 young larva; Kuzdeevskiy Region, river Kaltranchik near village Sarbala, 12.VIII.1949 and VII.1950, coll. B. Rohdendorf: 5 larvae. Buryatia: river Vitim near Baisa, 24-27.VI.1969, coll. V. Zherikhin and E. Shitnikova: 3 I(m), 1 S(f); river Vitim near Ust'-Dzinta, 25.VII.1964: 1 larva; Rohoshino: 8 imagoes. Chita Province: river ingoda near Chita, 26.VI.1981, coll. N. Sinitshenkova: 1 larva; river Shilka near Sretensk, 29.VI.1948: 1 larva. Yakutia, summer house Bedzhiches, 1.VIII.1925, coll. L. Bianki: 1 I(m). KAZAKHSTAN: East Kazakhstan, river Ulban near Ust'-Kamenogorsk, 13-16.VI.1965, coll. I. Sukacheva: 25 larvae; river Ulda, 16.VI.1965, coll. I. Sukacheva: 3 larvae. JAPAN: pref. Hiroshima: Higashi-Hiroshima, river Kurose, 18.VI.2000, coll. I. Tatarenko: 2 larvae; Hiroshima-City, Uokiri, Asakita-ku, river Yoshiyama, 20.VII.2000, coll. I. Tatarenko: 2 larvae; river Tojo in Tojo, 20.IX.2000, coll. I. Tatarenko: 7 larvae; river Shiniogawa, 31.VIII.1917, coll. Roshkovskiy: 1 larva.

Larva. As described by Kluge [1984].

Subimago. Cuticular COlORATION: Cuticle of thorax at most light with brown sclerites; mesonotum at most brown; 
most part of medioscutum and submedioscutum brown, posterior scutal protuberance brown except median part (as in Fig. 92). Cuticle of legs light brownish. Wings light brownish. Cuticle of abdomen light; cuticle of gonostyli brown.

Hypodermal coloration: Abdomen with brown maculation as in imago.

TEXTURE: On each leg $1^{\text {st }}$ tarsomere (shortened and fused with tibia) covered by microtrichiae of the same shape as microtrichiae on tibia; $2^{\text {nd }}-5^{\text {th }}$ tarsomeres covered by pointed microlepides.

Imago, male. As described by Kluge [1984]. Figure of genitals [Kluge, 1984: Fig. 8) is not accurate; correct one is given here (Fig. 68). Each penial projection [see Choroterpes/fg2 (3)] very long, sclerotized, pointed and armed by two narrow longitudinal flanges - median and dorsal ones; colorless spines small, located on edges of these flanges.

Egg. Chorion bears papillae and ridges going from one papilla to another [see Choroterpes/fg2 (1)] (Figs 70-73).

DIMENSION. Fore wing length $7-8 \mathrm{~mm}$.

DISTRIBUTION. East Siberia, Russian Far East, Mongolia, Korea, Japan.

\subsection{1-2. Euthraulus/g2 sumbarensis [Choroterpes]} Figs 69, 74-75

Original binomen: Choroterpes (Euthraulus) sumbarensis Kluge, 1984.

Possible binomina:

- Choroterpes (Euthraulus) sumbarensis;

- Euthraulus sumbarensis.

REFERENCES: Kluge, 1984: male imago and larva.

MATERIAL. Holotype and paratypes [Kluge, 1984]: Turkmenistan, river Sumbar near Karakala, 23-30.VI.1981, coll. N. Kluge: 1 L-S-Iㅇ, 2 L-S $\sigma^{7}$, 8 larvae; river Ay-Dere near Ay-Dere, 1-5.VII.1981, coll. N. Kluge: 2 L-S-I, 28 larvae; river Sumbar near Ay-Dere, 510.VII.1981, coll. N. Kluge: 10 L-S-I $\sigma^{\top}$ (among them holotype), 1 L$\mathrm{S}-\mathrm{I}+, 2 \mathrm{~L}-\mathrm{S} \sigma^{r}, 1 \mathrm{~L}-\mathrm{S}+, 12$ larvae.

Bauernfeind [1998] erroneously reported that holotype is "männchen Imago", while actually it represents larval, subimaginal and imaginal stages of the male specimen.

Larva. As described by Kluge [1984].

Subimago. Cuticular COlORATION: Cuticle of thorax at most light; mesonotum at most light brownish, only sutures (anteronotal transverse impression, anterolateral scutal costa, antelateroparapsidal and lateroparapsidal sutures) darker

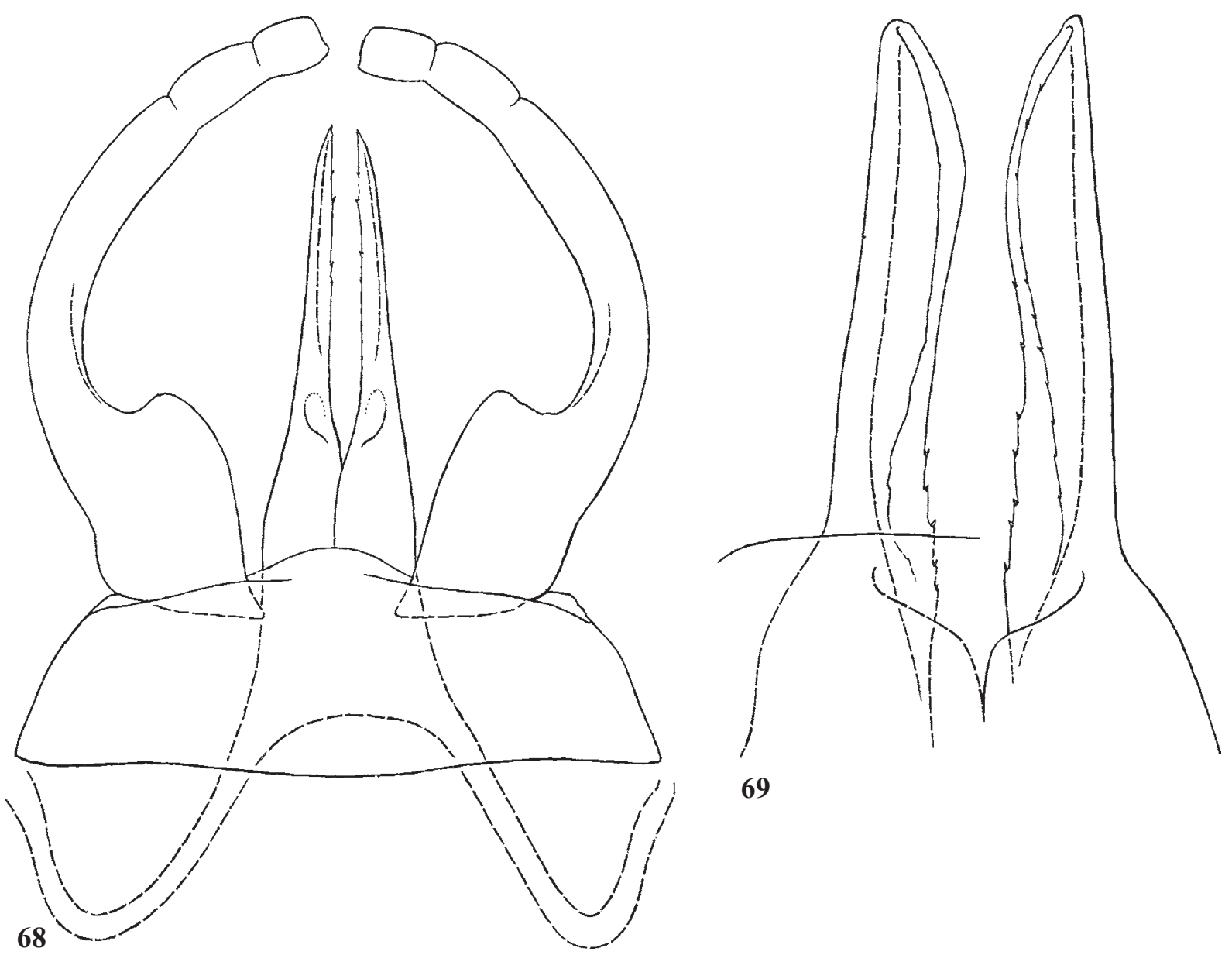

Figs 68-69. Choroterpes spp.: 68 - Ch. (Euthraulus) altioculus (holotype), genitals of male imago (ventral view); $69-C h$. (E.) sumbarensis (holotype), penis of male imago (ventral view; in the left — gonopore hidden by styliger, in the right — shown without styliger).

Рис. 68-69. Choroterpes spp.: 68 - Choroterpes (Euthraulus) altioculus (голотип), гениталии самца имаго (вентрально); 69 - Ch. (E.) sumbarensis (голотип), пенис самца имаго (вентрально; слева — гонопор скрыт стилигером, справа — показан без стилигера). 
brown. Cuticle of legs light. Wings light brownish. Cuticle of abdomen colorless, cuticle of gonostyli light brownish.

HyPODERMAL COLORATION: Abdomen with brown maculation as in imago.

TeXture: On each leg all tarsomeres covered by microtrichiae of the same shape as microtrichiae on tibia.

Imago, male. As described by Kluge [1984]. Each penis has proximal part so short, that at rest gonopores are hidden under styliger; apical projection [see Choroterpes/fg2 (3)] is unusually long, sclerotized and armed by two wide longitudinal flanges - median and medio-dorsal ones, each widened at its distal part; colorless spines small, locate on edges of these flanges (Fig. 69).

Egg. Chorion bears papillae and ridges going from one papilla to another [see Choroterpes/fg2 (1)] (Figs 74-75).

DIMENSION. Fore wing length 5-6 mm.

DISTRIBUTION. Kopetdag mountains in Turkmenistan.

\subsection{1-3. Euthraulus/g2 caucasicus sp.n. [Choroterpes] \\ Figs 76-97}

Original binomen: Choroterpes (Euthraulus) caucasicus sp.n. Possible binomina:

- Choroterpes (Euthraulus) caucasicus;

- Euthraulus caucasicus.

MATERIAL. Holotype: L-S-IO ${ }^{7}$ specimen [A](21)88\}: RUSSIA, Krasnodar Territory (= Krasnodarskiy Kray), river Psekups near railway station Chinary, 4.VI.1988, coll. N. Kluge. Paratypes: the same locality, 3-6.VI.1988, coll. N. Kluge: 5 L-S-IO', 6 L-S-Iㅇ, $1 \mathrm{~L}-\mathrm{S}$, 22 larvae; river Psekups railway station Goryaciy Kluch, 26-28.VIII.1985, coll. N. Kluge: 12 L-S-IO', 11 L-S-IP, 7 L-S $\sigma^{7}, 6$ L-S, 17 larvae; river Psekups railway station Fanagoriyskaya, 2527.VIII.1991, coll. N. Kluge: 1 L-S-IP, 8 larvae.

Larva. Cuticular coloration: Cuticle of head, pronotum and mesonotum light brownish, with diffusive markings; cuticle of legs and abdomen nearly colorless.
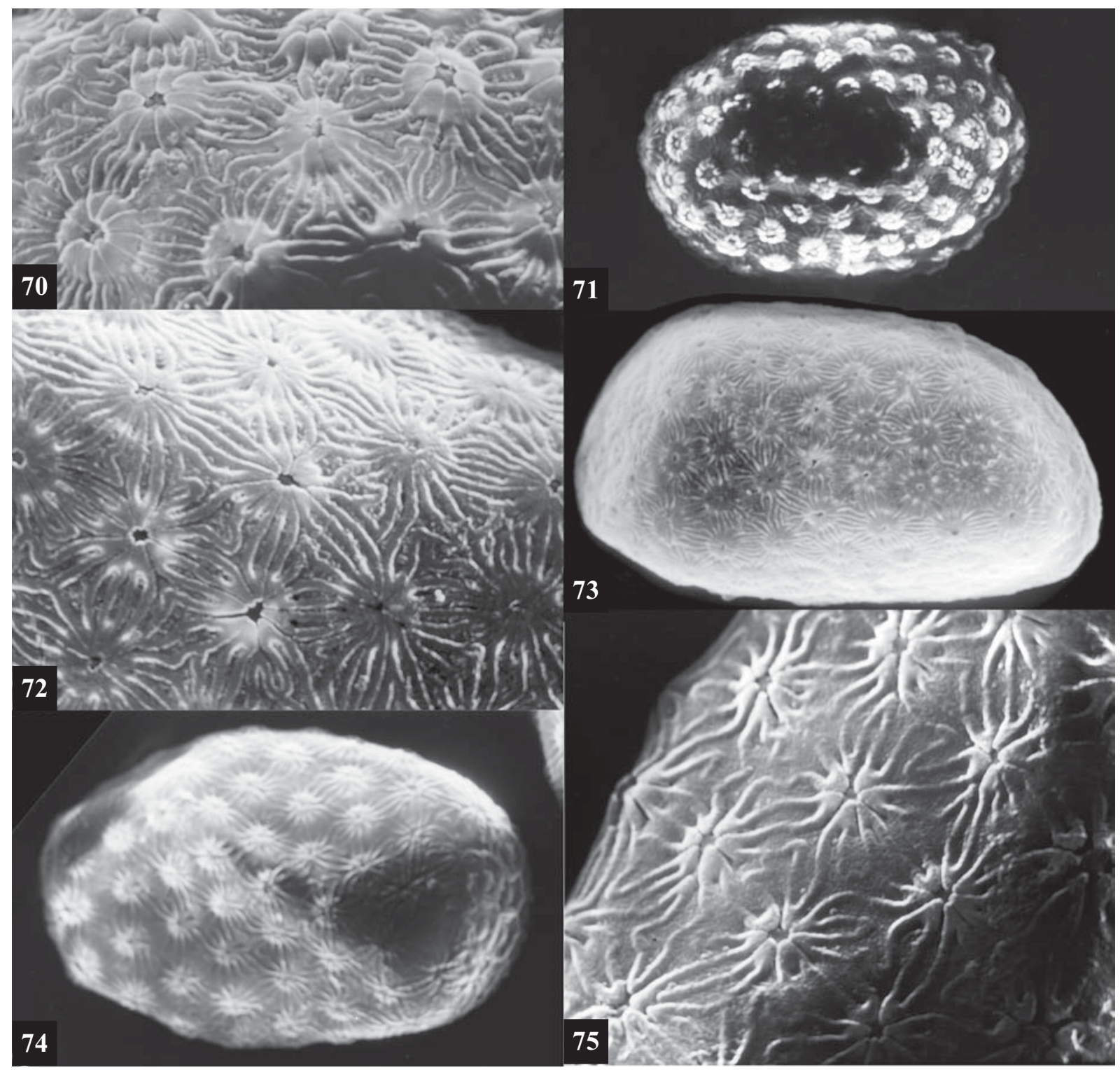

Figs 70-75. Euthraulus/g2, eggs: 70-73 - Choroterpes (Euthraulus) altioculus; 74-75-Ch. (E.) sumbarensis. Рис. 70-75. Euthraulus/g2, яйца: 70-73 - Choroterpes (Euthraulus) altioculus; 74-75-Ch. (E.) sumbarensis. 
Hypodermal COLORATION: Abdominal terga with brown maculation as in imago.

SHAPE AND SETATION: Labrum has median emargination moderate, with blunt denticles vestigial (Fig. 83) or absent
(Fig. 84); distal transverse setal row regular; proximal transverse setal row regular, as wide as distal. Mandibles with outer margin moderately convex (similar to Fig. 44). Medio-apical projection of maxilla moderately expressed

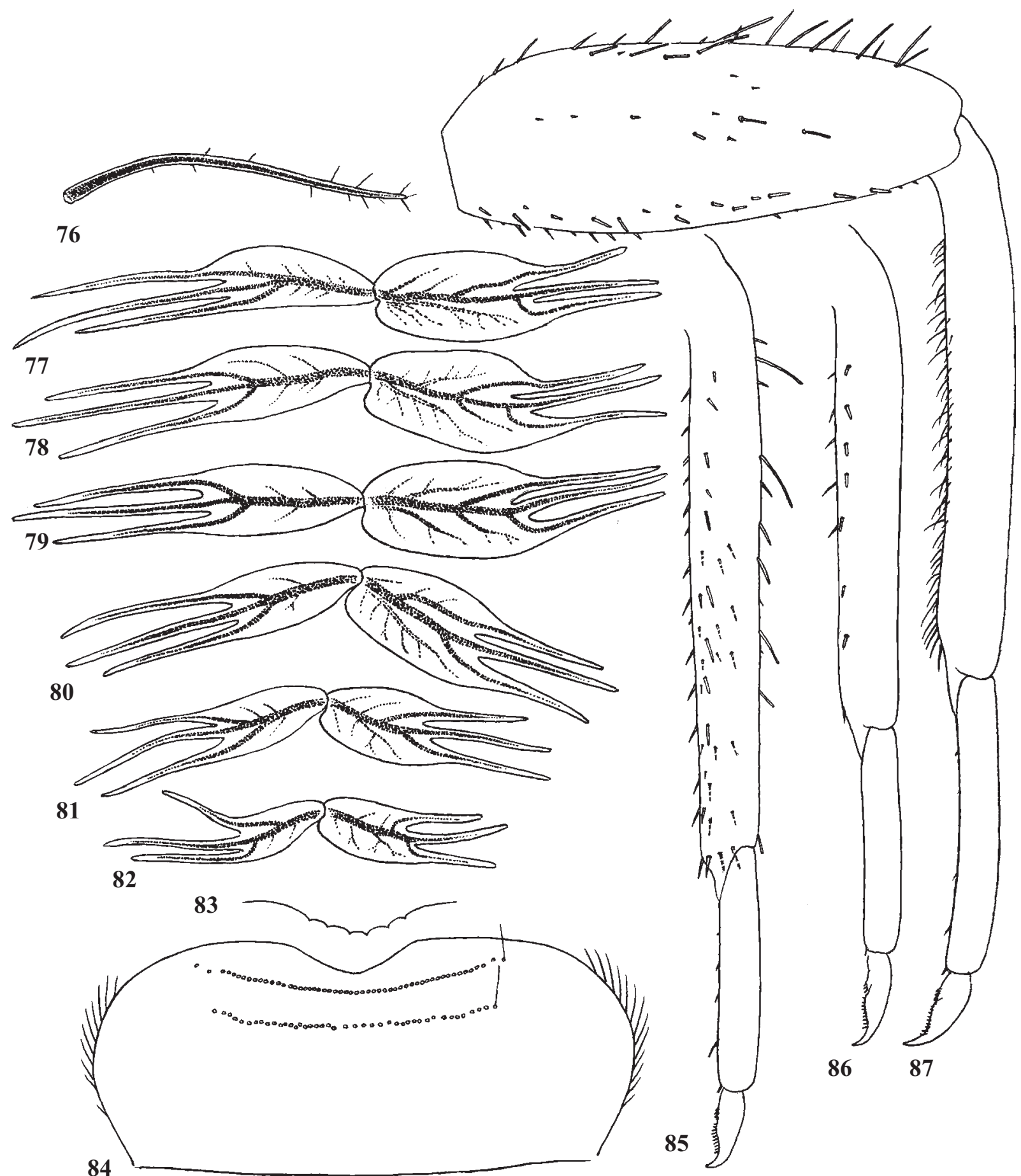

Figs 76-87. Choroterpes (Euthraulus) caucasicus sp.n., larva: 76-82 - tergalii I-VII (dorsal lamella bent to the left); 83 - anterior margin of labrum; 84 - labrum of another specimen, dorsal view (instead of setae of distal and proximal transverse rows, only their bases are shown); 85 - tibia and tarsus of hind leg (dorsal view); 86 — tibia and tarsus of middle leg (dorsal view); 87 — fore leg (dorsal view); 76-82, 84-87 - holotype.

Pис. 76-87. Choroterpes (Euthraulus) caucasicus sp.n., личинка: 76-82 - I-VII тергалии (дорсальный листок отогнут влево); 83 — передний край верхней губы; 84 - верхняя губа другого экземпляра, дорсально (вместо щетинок дистального и проксимального поперечных рядов показаны только их основания); 85 — голень и лапка задней ноги (дорсально); 86 — голень и лапка средней ноги (дорсально); 87 - передняя нога (дорсально); 76-82, 84-87 — голотип. 

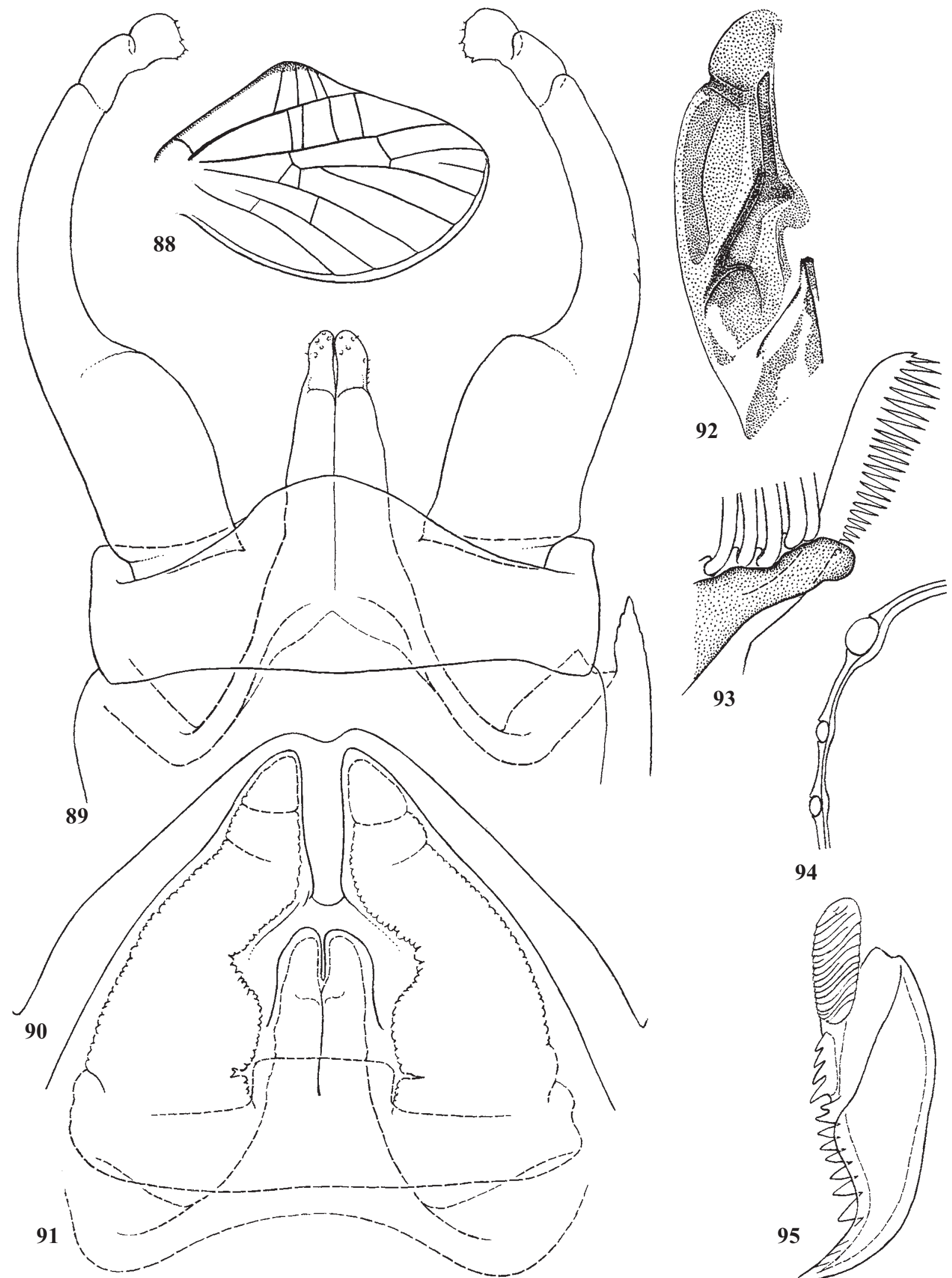

Figs 88-95. Choroterpes (Euthraulus) caucasicus sp.n.: 88 - hind wing; 89 - genitals of male imago (ventral view); 90 - outline of hind margin of abdominal sternum IX of mature female larva; 91 - larval protogonostyli and protopenis (dorsal view, shown by integral lines) with developing subimaginal genitals inside (shown by interrupted lines); 92 — exuviae of right half of subimaginal mesonotum; 93 - medio-apical projection of maxilla, ventral view (dotted); 94 - fragment of optic section of egg surface; 95 - larval claw; 88-89, 92, 95 - holotype. 


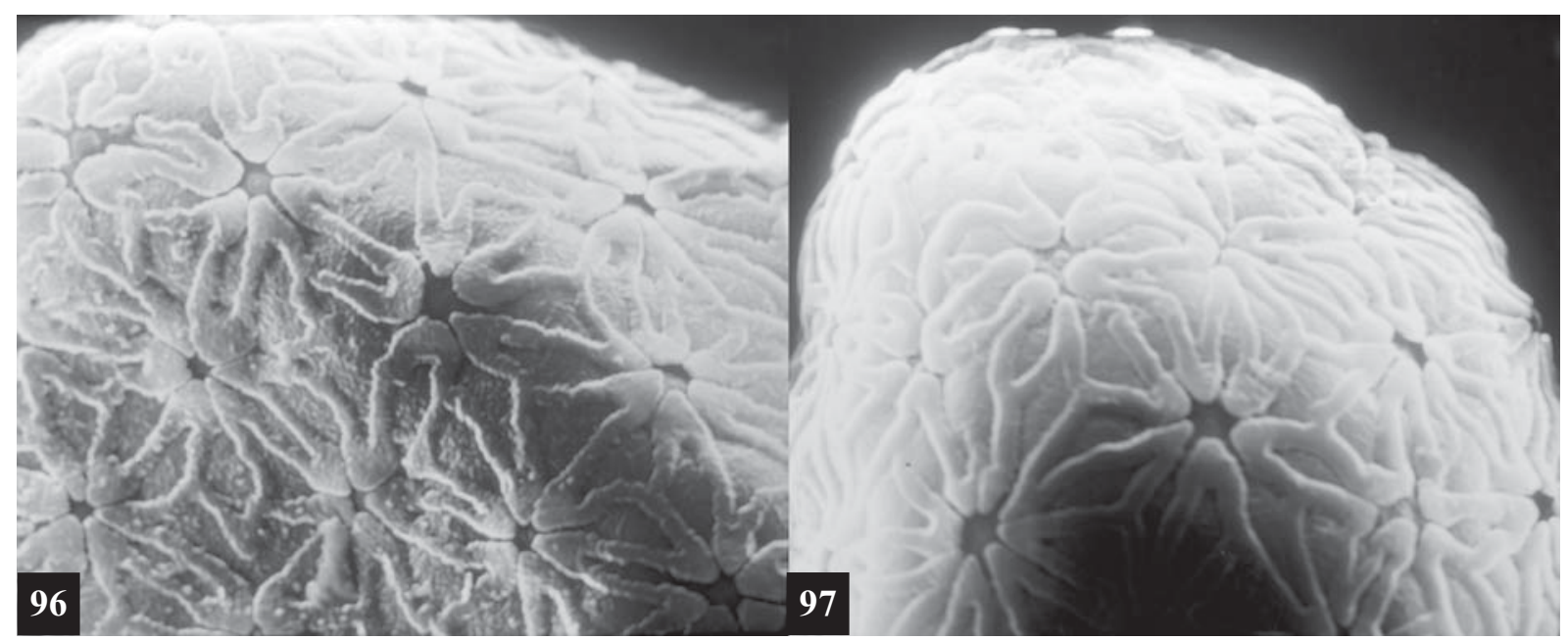

Figs 96-97. Choroterpes (Euthraulus) caucasicus sp.n., eggs.

Рис. 96-97. Choroterpes (Euthraulus) caucasicus sp.n., яйца.

(Fig. 93). Femur of fore leg widest proximally (Fig. 87), femora of middle and hind legs widest at middle (similar to Fig. 27). Femora with irregularly situated stout blunt setae of various length. Pectinate setae on ventral side of hind femur pointed and curved, form a single irregular row parallel to inner margin of femur. Stout setae on inner side of fore tibia situated densely and irregularly, bipectinate (pointed, with two rows of stout pointed processes by sides). Inner side of middle and hind tibia with a sparse row of stout setae; outer side of hind tibia with stout setae of variable length, as on outer side of femur. Outer sides of all tibiae with irregularly situated thin hairs, whose length exceed tibia width (not shown in Figs 85-87). Abdomen without stout setae. Posterolateral spines expressed on abdominal segment VII-IX. Hind margins of abdominal terga with pointed denticles, whose size increases from tergum I to tergum X; sterna without denticles. Tergalii IIVII [see Euthraulus (1)] have all three processes of both lamellae well developed; anal-proximal projection of ventral lamella poorly expressed (Figs 77-82). Protogonostyli of male larva narrowly separated; protopenes convergent, completely hidden under sternum XI (Fig. 91). Female larva has hind margin of abdominal sternum IX slightly incised (Fig. 90).

Subimago. Cuticular coloration: Cuticle of thorax at most light with brown sclerites; mesonotum at most brown: most part of medioscutum brown, most part of submedioscutum somewhat lighter brown, posterior scutal protuberance brown except median part (Fig. 92). Cuticle of legs light brownish. Wings light brownish. Cuticle of abdomen colorless, cuticle of gonostyli brown.

HYPODERMAL COLORATION: Abdomen with brown maculation as in imago.

Texture: On fore leg $1^{\text {st }}$ tarsomere (shortened and fused with tibia) covered by microtrichiae of the same shape as microtrichiae on tibia; $2^{\text {nd }}-5^{\text {th }}$ tarsomeres covered by pointed microlepides. On middle and hind legs $1^{\text {st }}-4^{\text {th }}$ tarsomeres covered by microtrichiae of the same shape as microtrichiae on tibia; $5^{\text {th }}$ tarsomere covered by pointed microlepides.

Imago, male. Head brown; dorsal eyes not elevated [as in Kluge, 1984: Fig.22], brownish-orange. Thorax brown with ocher. On fore wing basal sclerites brownish, veins light, membrane colorless; pterostigma whitish, with simple oblique crossveins. Hind wing with costal projection blunt (Fig. 88). Legs light brownish; on each leg cuticle of extreme femur base and knee area (apex of femur and base of tibia) colored by darker brown. Each abdominal tergum with a pair of large diffusive dark brown hypodermal maculae, which occupy its most part except for ocher stripe bordering anterior margin, ocher stripe bordering posterior margin, ocher medial longitudinal stripe and ocher areas laterad of tracheal trunks. Sterna I-VIII uniformly ocher, last abdominal ganglion tinged with dark brown. Abdominal sternum IX with styliger has middle part ocher, periphery areas (anterior, posterior and lateral) brown. Gonostyli light, ocher. $1^{\text {st }}+2^{\text {nd }}$ segments of gonostylus with inner margin convex. Penes brown; each penis has apical projection [see Choroterpes/fg2 (3)] not long, with apex roundish; its denticles are very small (Fig. 89). Caudalii light.

Imago, female. Coloration as in male. Posterior plate of abdominal sternum IX apically slightly incised, as in larva (as in Fig. 90).

Egg. Yellow, oval. Chorion bears evenly dispersed papillae and ridges going from one papilla to another [see Choroterpes/fg2 (1)]; papillae small (Figs 96-97), one pole bears larger papillae (Fig. 94).

DIMENSION. Fore wing length 5-6 mm.

DISTRIBUTION. Western Caucasus.

COMPARISON. In larval and adult structure $C h .(E$. caucasicus sp.n. is similar to Ch. (E. ) assimilis Gaino et Sowa, 1985 (whose male imago is unknown). Unlike Ch. (E.) caucasicus sp.n. and most other species of Choroterpes, $C h$. (E. ) assimilis has no characteristic relief on egg surface [see Choroterpes/fg2 (1)].

Рис. 88-95. Choroterpes (Euthraulus) caucasicus sp.n.: 88 - заднее крыло; 89 - гениталии самца имаго (вентрально); 90 очертание заднего края IX стернита брюшка зрелой личинки самки; 91 - протогоностили и протопенис личинки (дорсально, показаны сплошными линиями) с развивающимися субимагинальными гениталиями внутри (показаны прерывистыми линиями); 92 - экзувий правой половины субимагинального мезонотума; 93 - медио-апикальный выступ максиллы, вентрально (пунктирован); 94 - участок оптического среза поверхности яйца; 95 - коготок личинки; 88-89, 92, 95 - голотип. 


\subsection{1-4. Euthraulus/g2 signata [Cloe $]$} Figs $98-116$

Original binomen: Cloe signata Hagen, 1858.

Possible binomina:

- Choroterpes (Euthraulus) signatus;

- Euthraulus signatus.

REFERENCES: Eaton, 1883-1888: imago and subimago (Thraulus signatus).

MATERIAL. Sri Lanka, coll. N. Kluge \& L. Sheyko: boundarbetween Uva province and Central province, tributary of river Uma near Randenigala dam, 13-14.I.2011: 1 L-S-I $\sigma^{7}, 1$ L-S-Iㅇ, 16 larvae. Uva province, Badulla district, Haputale Forest and river Lemastota Oya, 15-23.I.2011: 5 L-S-IO', 3 L-S-I,+ 2 L-S +20 larvae. Sabaragamuwa province, river Seetha Sangula, Dalhausie near Sri Pada (Adam's Peak), 24-26.I.2011: 14 larvae. Central province, river Mahaveli Ganga in Ginigathhena (17 km N Hatton), 31.I-3.II.2011: 1 L-S-IO'.

Larva. Cuticular COlORATION: Cuticle of head, thoracic terga and pleura brown with contrasting ocher blanks; cuticle of thoracic sterna light. Cuticle of legs variable, either uniformly light, or with dark maculae: femur can have large macula in middle and large macula near apex; hind femur can have longitudinal macula stretching from femur base to the middle macula; tibia can be darkened near base; tarsus can be dark except extreme base and distal part. Cuticle of abdominal terga variable, either uniformly light, or with contrasting dark ornament adjacent to fore, hind and/or lateral margins of each or some terga. Cuticle of abdominal sterna either uniformly light or with dark maculae adjacent to fore margins of some sterna.

Hypodermal coloration: Head, thorax and abdomen with brown maculation. Each femur pale, with dark brow maculae in middle and near apex, as in imago. Color of tergalii variable: either nearly colorless, or dark gray, with dorsal lamella nearly black.

SHAPE AND SETATION: Labrum not wide, its median emargination rather deep, with blunt denticles; distal transverse setal row regular; proximal transverse setal row regular, narrower than distal (Fig. 107). Mandibles with outer margin moderately convex (Fig. 110). Medio-apical projection of maxilla moderately expressed (similar to Fig. 93). Femur of fore leg widest proximally, femora of middle and hind legs widest at middle (similar to Figs 24, 27). Pectinate setae on ventral side of hind femur pointed and curved, form a stripe parallel to inner margin of femur (similar to Figs 150-151). Stout setae on inner side of fore tibia dense and arranged in 3 nearly regular rows (as in Fig. 25), pointed and bipectinate (with two rows of stout pointed processes by sides). Inner side of middle and hind tibia with a sparse row of stout setae; outer side of hind tibia with stout setae of variable length, as on outer side of femur. Outer sides of all tibiae with irregularly situated thin hairs, whose length exceed tibia width. Abdomen without stout setae. Posterolateral spines well expressed on abdominal segments beginning from IV-VI to IX. Posterolateral spines on terga VIII and IX have inner convexities very prominent, often projected caudally (Figs 108, 109). Hind margins of abdominal terga with pointed denticles, whose size increases from tergum I to tergum $\mathrm{X}$; sterna without denticles. Tergalii II-VI [see Euthraulus (1)] have all three processes of both lamellae well developed; tergalius VII variable: dorsal lamella has costal process either vestigial (Fig. 104) or well-developed (Fig. 105); ventral lamella has all three processes well developed. Costal and ventral processes of ventral lamella widened proximally. Anal-proximal projection of ventral lamella poorly expressed on tergalius II, very prominent on tergalii III-VII (Figs 99-104). Protogonostyli of male larva narrowly separated; protopenes conver- gent, completely hidden under sternum XI (similar to Fig. 91). Female larva has hind margin of abdominal sternum IX slightly incised (similar to Fig. 90).

Subimago. Cuticular COlORATION: Cuticle of thorax at most light with brown sclerites; mesonotum at most brown; most part of medioscutum and submedioscutum brown, posterior scutal protuberance brown except median part (as in Fig. 92). Cuticle of legs light brownish. Wings light brownish. Cuticle of abdominal terga light brownish; abdominal sterna I-VIII colorless; sternum IX brown anteriorly and laterally, with colorless semicircular area medially-posteriorly; cuticle of gonostyli brown.

Hypodermal COLORATION: Abdomen and femora with brown maculation as in imago.

Texture: On each leg $1^{\text {st }}$ tarsomere (shortened and fused with tibia) covered by microtrichiae of the same shape as microtrichiae on tibia; $2^{\text {nd }}-5^{\text {th }}$ tarsomeres covered by pointed microlepides.

Imago, male. Head brown; dorsal eyes not elevated [as in Kluge, 1984: Fig.22], brownish-orange. Thorax brown with ocher. On fore wing basal part, including costal brace, brown, other membrane colorless; veins light; pterostigma whitish, with 4-7 simple crossveins. Hind wing with costal projection blunt (Fig. 106). Each leg has cuticle colorless, with knee area (apex of femur and base of tibia) light brown; hypodermal pigmentation forms wide black band at middle of femur, wide black band at apex of femur, sometimes black spot in proximal half of femur, sometimes small band near apex of tibia; sometimes tibia and tarsus brown. Abdominal terga at most dark brown, with darker and lighter areas repeated on terga I-IX. Sterna I-VIII lighter, last abdominal ganglion tinged with dark brown. Abdominal sternum IX brown anteriorly and laterally, with colorless semicircular area medially-posteriorly; styliger and gonostyli brown. Styliger strongly narrows from base toward apex; $1^{\text {st }}+2^{\text {nd }}$ segments of gonostylus with inner margin convex. Penes brown; each penis has apical projection [see Choroterpes/fg2 (3)] moderately long, conic, slightly bent medially-dorsally; its denticles are very small. In other respects genitals are quite variable: posterior margin of styliger varies from slightly concave (Fig. 115) to strongly convex (Fig. 111); thick proximal part of gonostylus varies from long and smoothly projected (Figs 114-115) to short and sharply projected (Figs 111-112); shape of penis is rather variable. Caudalii light, with dark brown ring at each joining.

Imago, female. Coloration as in male. Posterior plate of abdominal sternum IX with small apical incision.

Egg. Yellow, oval. Chorion bears evenly dispersed papillae and ridges going from one papilla to another [see Choroterpes/fg2 (1)]; papillae small, one pole bears larger papillae.

DIMENSION. Variable, fore wing length 4-7 $\mathrm{mm}$.

DISTRIBUTION. Sri Lanka.

COMMENTS. Ch. (E.) signatus has great individual variability in size, cuticular coloration of larval abdomen and legs, hypodermal coloration of tergalii, shape of male imaginal styliger, gonostyli and penis. Comparison of 7 male imagoes reared from larvae allows to conclude that they belong to a single species. In subimaginal stage individual variability of gonostyli shape is less than in imaginal stage (compare Figs 112 and 113; 115 and 116).

Eaton [1883-1888] reported that with the type specimens of Cloe signatus stood two specimens of two other species, numbered 32 and 37 . Judging by his descriptions, the specimen No.32 can belong to Megaglena brincki Peters et Edmunds, 1970. Systematic position of the specimen 37, whose femora are colorless, is unclear. 


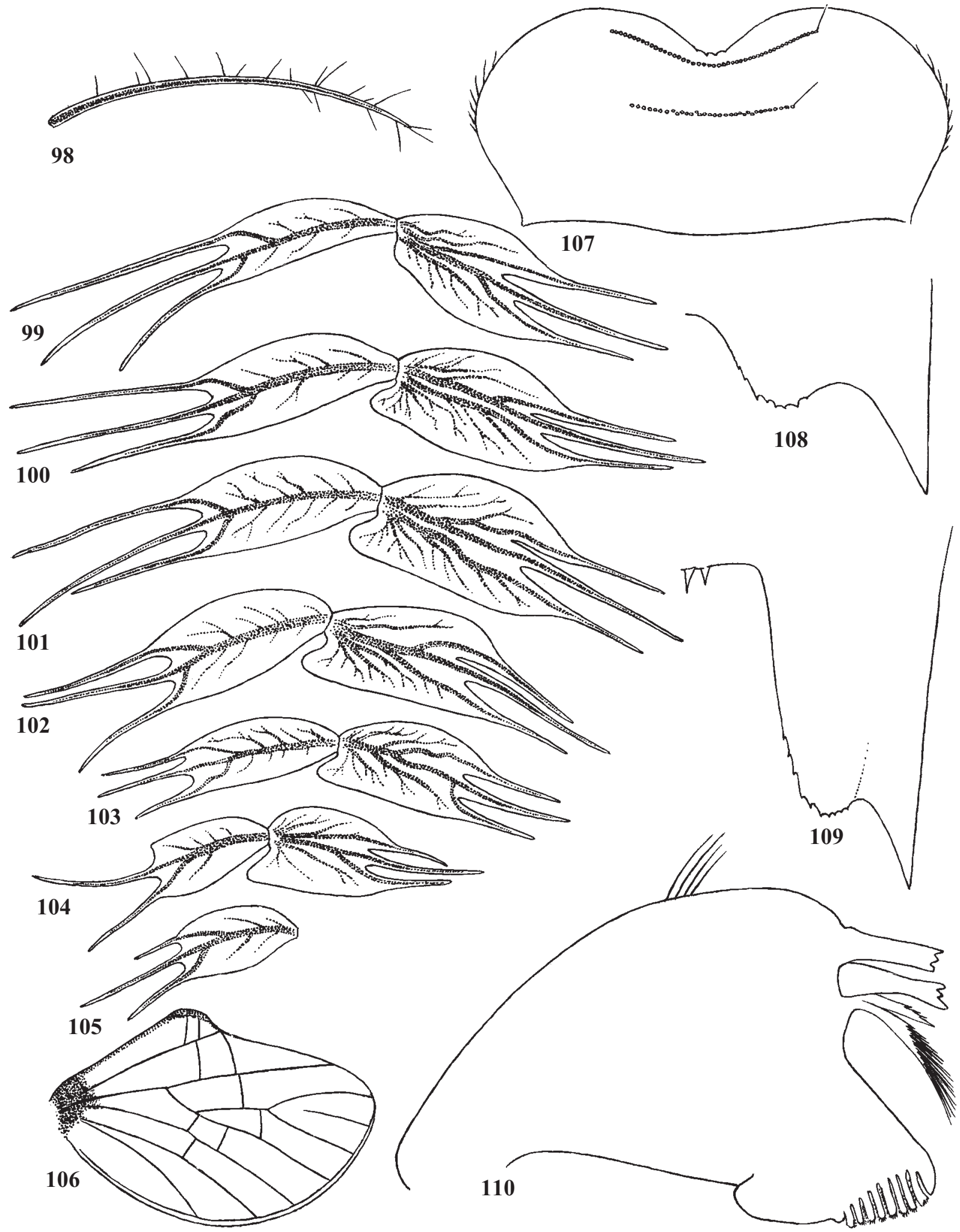

Figs 98-110. Choroterpes (Euthraulus) signatus: 98-104 - tergalii I-VII (dorsal lamella bent to the left); 105 — dorsal lamella of tergalius VII, another specimen; 106 - hind wing; 107 - labrum, dorsal view (instead of setae of distal and proximal transverse rows, only their bases are shown); 108-109 — posterolateral spines of larval abdominal terga VIII and IX; 110 — left mandible.

Рис. 98-110. Choroterpes (Euthraulus) signatus: 98-104 - I-VII тергалии (дорсальный листок отогнут влево); 105 — дорсальный листок VII тергалии, другой экземпляр; 106 - заднее крыло; 107 - верхняя губа, дорсально (вместо щетинок дистального и проксимального поперечных рядов показаны только их основания); 108-109 - постеролатеральные шипы VIII и IX тергитов брюшка личинки; 110 - левая мандибула. 

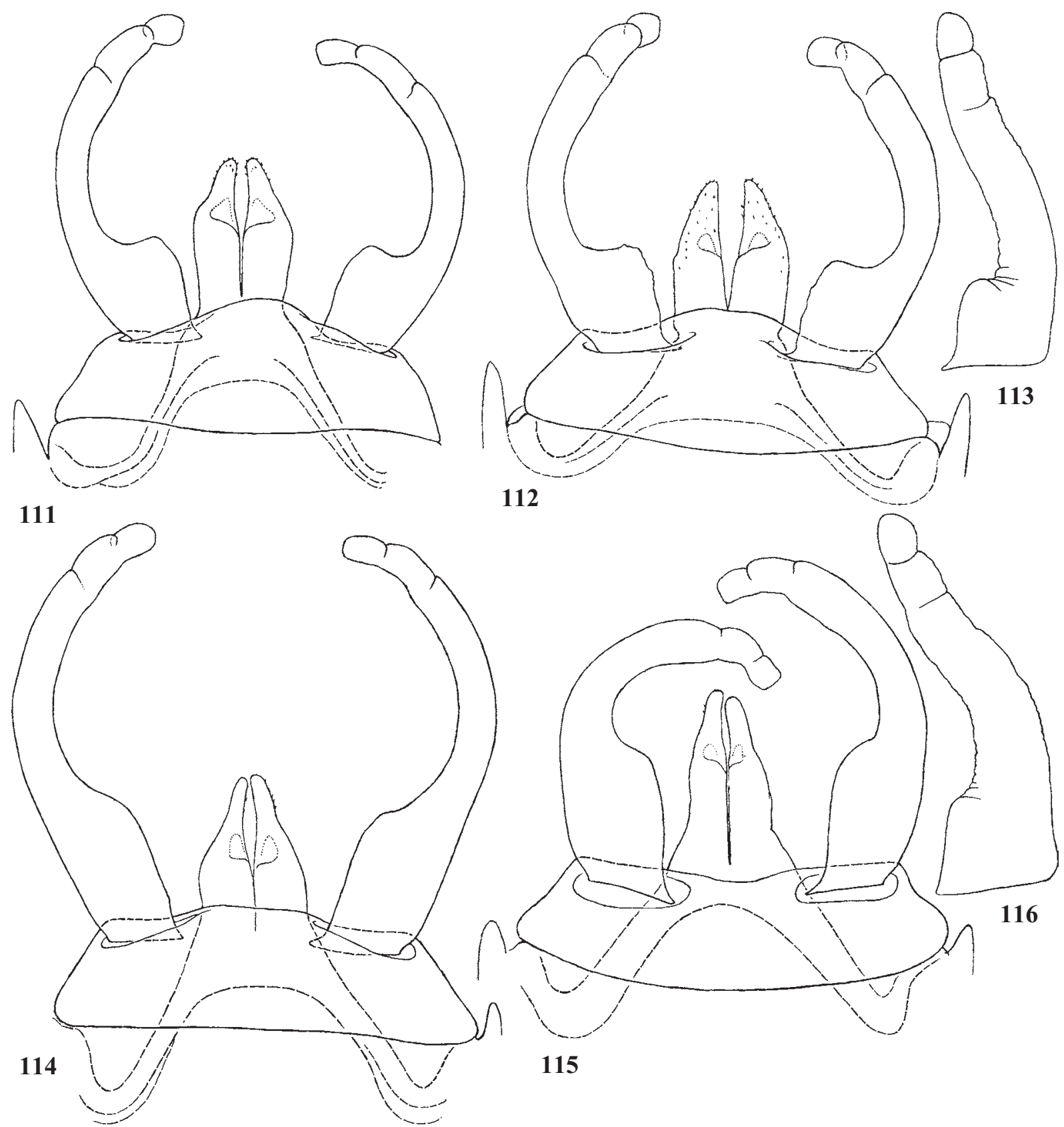

Figs 111-116. Choroterpes (Euthraulus) signatus, genitals of male imagoes reared from larvae: 111 — from River Uma; 112 - from Ginigathhena; 113 - subimaginal gonostylus of the same specimen; $114-115$ - from Haputale; 116 - subimaginal gonostylus of the same specimen.

Рис. 111-116. Choroterpes (Euthraulus) signatus, гениталии самцов имаго, выведенных из личинок: 111 — из реки Ума; 112 из Гинигатхены; 113 - субимагинальный гоностиль того же экземпляра; 114-115 - из Хапутале; 116 - субимагинальный гоностиль того же экземпляра.

\subsubsection{1-5. Euthraulus/g2 bugandensis [Euthraulus]}

Original binomen: Euthraulus bugandensis Kimmins 1956. Possible binomina:

- Choroterpes (Euthraulus) bugandensis;

- Euthraulus bugandensis.

REFERENCES: Kimmins, 1956: imago; Sartori \& Gillies, 1990: larva and egg.

MATERIAL. Uganda, Victoria Nile at Bujagali Falls, 6-

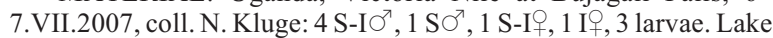
Viktoria, Jinja, 6-10.VII.2007, coll. N. Kluge: 1 S-IO', 2 IO'.

\subsection{Monophyllus/g(1), or Monophyllus} Figs $117-128$

Systematic position: Choroterpes/fg1-Choroterpes/fg2-Euthraulus/g1-Monophyllus.

Hierarchical typified name: Monophyllus/g(1) [g: Monophyllus Kluge, subgen.n.; type species: Choroterpes (Monophyllus) monophyllus Kluge, sp.n.].

Possible rank-based names:

- subgenus Monophyllus in genus Choroterpes;

- subgenus Monophyllus in genus Euthraulus; 
— genus Monophyllus.

Autapomorphy.

(1) Tergalii II-VII [initially bilamellate - see Choroterpes/fg2 (2)] are unilamellate. Each lamella has all three apical processes subequal, long and slender (Figs 121-126) (as in Euthraulus).

Distribution and species composition. A single species is known from Hainan Island.

\subsection{2-1. Monophyllus/g(1) monophyllus sp.n.}

[Choroterpes]

Figs 117-128

Original binomen: Choroterpes (Monophyllus) monophyllus sp.n. Possible binomina:

- Choroterpes (Monophyllus) monophyllus;

- Choroterpes (Euthraulus) monophyllus;

- Euthraulus (Monophyllus) monophyllus;

- Monophyllus monophyllus.

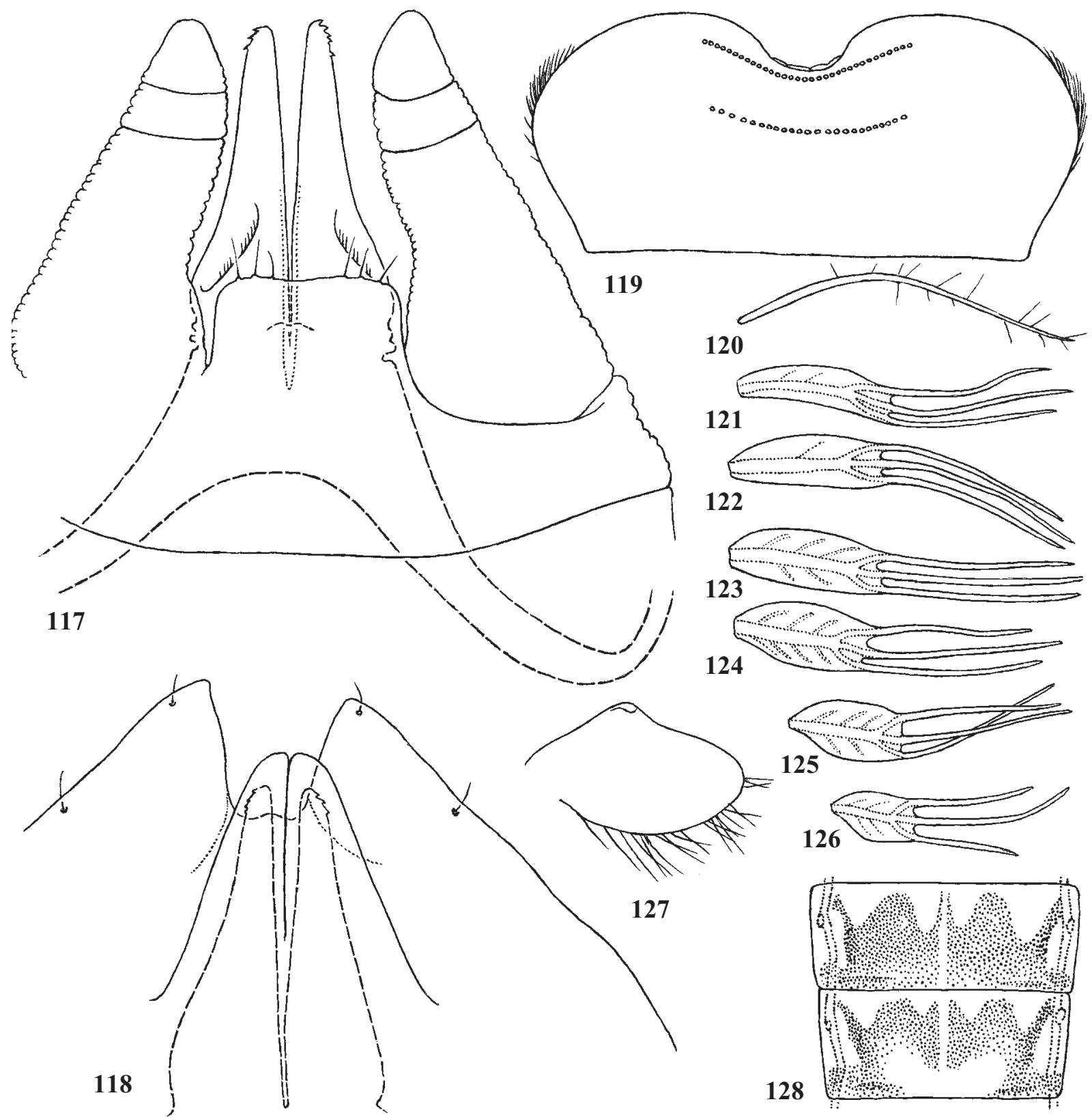

Figs 117-128. Choroterpes (Monophyllus) monophyllus sp.n.: 117 — subimaginal genitals with crumpled gonostyli, extracted from larva (ventral view); 118 — larval protogonostyli and protopenis (dorsal view; subimaginal penis shown by interrupted line); 119 — labrum, dorsal view (instead of setae of distal and proximal transverse rows, only their bases are shown); 120-126 — tergalii I-VII; 127 — outline of subimaginal hind wing, extracted from larva and spread; 128 - hypodermal coloration of abdominal terga VI and VII; 117, 119-128 - holotype.

Рис. 117-128. Choroterpes (Monophyllus) monophyllus sp.n.: 117 - субимагинальные гениталии со смятыми гоностилями, отпрепарированные из личинки (вентрально); 118 - личиночные протогоностили и протопенис (дорсально; субимагинальный пенис показан прерывистой линией); 119 - верхняя губа, дорсально (вместо щетинок дистального и проксимального поперечных рядов показаны только их основания); 120-126 - I-VII тергалии; 127 — очертание субимагинального заднего крыла, отпрепарированного из личинки и расправленного; 128 - гиподермальная окраска VI и VII тергитов брюшка; 117, 119-128 — голотип. 
MATERIAL. Holotype: L/S $\sigma^{7}$, China, Hainan, Miao-Li, 19.XII.1957, coll. N. Andrianova. Paratypes: the same locality, 2 male larvae.

Larva. Cuticular COloration: Cuticle of head, pronotum and mesonotum brown, with diffusive markings; cuticle of legs and abdomen light brownish, nearly unicolorous, without contrasting markings.

HyPODERMAL COLORATION: Legs light; each femur with a dark brown spot at middle and a dark brown band near apex; fore femur also with a brown spot near base. Each abdominal tergum II-VI at most part brown with lighter blanks adjacent to anterior margin; each tergum VII-IX, besides anterior blanks, with a pair of large blanks adjacent to posterior margin (Fig. 128).

SHAPE AND SETATION: Labrum not wide, its median emargination rather deep, with blunt denticles; both distal and proximal transverse setal rows regular (Fig. 119). Mandibles with outer margin moderately convex (similar to Fig. 110). Medio-apical projection of maxilla moderately expressed (similar to Fig. 93). Femur of fore leg widest proximally, femora of middle and hind legs widest at middle (similar to Figs 24, 27). Femora with irregularly situated stout setae of various length. Ventral side of hind femur with irregularly situated curved pectinate setae (similar to Figs 150-151). Stout setae on inner side of fore tibia dense and arranged in 3 nearly regular rows (as in Fig. 25), pointed and pectinate. Inner side of middle tibia with 2 or 1 stout setae. Inner side of hind tibia with a sparse row of stout setae; outer side of hind tibia with stout setae of variable length, as on outer side of femur (similar to Fig. 85). Outer sides of all tibiae with irregularly situated thin hairs, whose length exceed tibia width. Abdomen without stout setae. Posterolateral spines short and obtuse. Hind margins of abdominal terga with pointed denticles, whose size increases from tergum I to tergum X; sterna without denticles. Tergalii unilamellate (Figs 120-126). Protogonostyli of male larva narrowly separated; protopenes convergent, narrowed toward apex, long, projected between protogonostyli (Fig. 118).

Subimago (extracted from mature larva). CUTICULAR COLORATION: Cuticle of thorax at most light with brown sclerites; mesonotum at most brown; most part of medioscutum and submedioscutum brown, posterior scutal protuberance brown except median margin (as in Fig. 92). Fore and hind wings light, with dark brown spot near base, including costal brace.

Hypodermal COLORATION: Femora and abdomen with hypodermal coloration as in larva.

TEXTURE: On each leg $1^{\text {st }}$ tarsomere (shortened and fused with tibia) covered by microtrichiae of the same shape as microtrichiae on tibia; $2^{\text {nd }}-5^{\text {th }}$ tarsomeres covered by pointed microlepides.

Imago male. Unknown. Judging by subimaginal genitals, extracted from larva, each penis has apical projection [see Choroterpes/fg2 (3)] long, and conic; its denticles are relatively large, located on tip of penis and directed proximally (Fig. 117).

Female. Unknown.

Egg. Unknown.

DIMENSION. Fore wing length $4 \mathrm{~mm}$.

DISTRIBUTION. Hainan Island.

\subsection{Dilatognathus/g(1), or Dilatognathus Figs 129-133}

Systematic position: Choroterpes/fg 1 - Choroterpes/fg2-Euthraulus/g1-Dilatognathus.

Hierarchical typified name: Dilatognathus/g(1) [g: Dilatognathus Kluge, subgen.n.; type species: Choroterpes (Dilatognathus) cataractae Kluge, sp.n.]
Possible rank-based names:

- subgenus Dilatognathus in genus Choroterpes;

- subgenus Dilatognathus in genus Euthraulus;

- genus Dilatognathus.

Autapomorphies.

(1) Mouth apparatus has following modifications:

Labrum is widened, its median incision (characteristic for Atalophleboculata) is widened; proximal transverse row of setae (characteristic for Atalophlebopectinata) is shifted to proximal part of labrum and can be interrupted medially (Fig. 133).

Maxilla has inner-apical angle produced as tusk-like process; pectinate setae of ventro-apical row (characteristic for Leptophlebia/fg1) are vestigial and located on the tusklike process (Fig. 131). In other respects maxilla differs in young larvae and in ultimolarva:

In young larva the single pectinate dentiseta [see Atalophlebomaxillata (2)] is straightened and parallel to the tusklike process; the ventro-apical flange [see Atalophlebomaxillata (1)] is shortened (Fig. 132).

In ultimolarva (i.e., last-instar larva, or nymph) the tusklike process is long, the dentiseta is lost and the ventro-apical flange is very low and poorly expressed (Fig. 129).

Maxillary palp is elongate and bears long filtering setae: $2^{\text {nd }}$ segment in apical part of inner side has a few such setae forming a longitudinal row; $3^{\text {rd }}$ (terminal) segment has a proximal semicircular transverse row of such setae on its inner side and fields of irregularly situated setae along its ventral and dorsal sides (Figs 130-131).

Labium has paraglossae widened, expanded laterally [Peters \& Edmunds, 1970: Fig. 165]. Labial palp is elongate and bears long filtering setae which form regular longitudinal rows: $2^{\text {nd }}$ segment has a double row on outer side and a row on dorsal side; $3^{\text {rd }}$ segment has a row on outer side and a row on inner side; dorsal side of $3^{\text {rd }}$ segment also bears smaller irregularly situated setae (Fig. 139).

(2) Tergalius I [initially different from others - see Choroterpes/fg1 (1)] is lost, thus only tergalii II-VII are present [see (3)].

(3) Tergalii have the same structure in all species (Figs 138, 140, 141). Each of two lamellae of tergalii II-VII is widened, its 3 apical processes [see Choroterpes/fg2 (2)] are brought together, side processes of ventral lamella are wide basally. Each tergalius II-VI normally has all 6 apical processes (only in individual cases some processes can be absent); tergalius VII has 5 apical processes only: its dorsal lamella has no costal process (Fig. 138). Tergalii II-V have equal size and shape, tergalius VI is smaller, tergalius VII (with 5 apical processes) is the smallest.

Discussion: status of the generic name Choroterpides. Larvae of the taxon described here as Dilatognathus subgen.n., are known under the generic name Choroterpides Ulmer, 1939. Ulmer [1939] established this genus basing on imagoes and larvae, which he attributed to two species - Choroterpides exigua (Eaton, 1884) and Choroterpides major Ulmer, 1939. According to original designation [Ulmer, 1939: 495], the type species of Choroterpides is Ch. exigua (originally Thraulus exiguus Eaton, 1884, but not Choroterpes exiguus Eaton, 1892). Originally, Thraulus exiguus was described from "Lahat, Palembang" in southern Sumatra; its type specimen is lost [Ulmer, 1939; Kimmins, 1960]. Ulmer's description of "Choroterpides exigua" is based on specimens from Java (mainly from Buitenzorg, now Bogor) and southern Sumatra. His figures of male imaginal genitals [Ulmer, 1939: figures 40 and 41] are different from the original description: in the original description [Eaton, 1883-1888: P1. 13, Fig. 20*2] styliger is strongly convex; last segment of gonostylus is very small (much narrower than previous seg- 
ments); penis is very small (shorter than widened part of gonostylus) and strongly narrowed in the middle. There is no reason to regard the male imagoes describes by Eaton and Ulmer as belonging to the same species. Recently, most Indonesian species of mayflies remain to be undescribed, so the type of Thraulus exiguus can belong to a species which has not been rediscovered yet. Ulmer had no reared male imagoes, so his association of larvae and imagoes of two species is not grounded. The taxon Choroterpides, as described by Ulmer, is well characterized by larval structure (specialized mouth apparatus and characteristic structure of tergalii), but has no sufficient diagnosis for adults. So the original description of Choroterpides should be regarded as based on misidentified type species. According to the Article 70.3 of the International Code of Zoological Nomenclature, "If an author discovers that a type species was misidentified ... the author may select, and thereby fix as type species, the species that will, in his or her judgment, best serve stability and universality, either (70.3.1.) the nominal species previously cited as type species [Arts. 68, 69], or (70.3.2.) the taxonomic species actually involved in the misidentification". As no one species has been sufficiently described basing on reared material, I am fixing as the type species of Choroterpides the nominal species previously cited as type species - i.e., the species described by Eaton as Thraulus exiguus. According to this type fixation, the generic name Choroterpides belongs to a taxon of unclear systematic position. Judging by strongly convex styliger, it can belong to the plesiomorphon Euthraulus/g2; in this case Choroterpides Ulmer, 1939 is a junior synonym of Euthraulus Barnard, 1932.

Originally, the genus Choroterpides was characterized by imaginal and larval characters; its imago was opposed to Choroterpes as having narrower hind wings and 3-segmented gonostyli, while Choroterpes was regarded to have 4-segmented gonostyli [Ulmer, 1939]. Actually, number of gonostyli segments is the same (see Discussion on Choroterpes/fg2 above). Hind wing of Choroterpes s.str. have variable width and shape.

Peters and Edmunds [1970] suggested to separate imagoes of Choroterpides by a single character - presence of a distance between posterior margin of fore wing and a vein bordering this margin. Actually this distance is present in all Choroterpes/fg2 (Figs 40, 50, 88, 106, 136) [Kluge, 1984: Figs 6, 25].

Distribution and species composition. Oriental Region. Choroterpes (Dilatognathus) cataractae sp.n. from Lombok is described below. The species originally described from Java as Choroterpides major Ulmer, 1939, belongs to Dilatognathus - Choroterpes (Dilatognathus) major (Ulmer, 1939), comb.n. Ulmer distinguished imago of major [Choroterpides] from "Choroterpides exigua" by concavity on costal projection of hind wing [Ulmer, 1939: 498]; actually, this character can vary individually (Figs 136-137). Ulmer distinguished larvae of major [Choroterpides] from "Choroterpides exigua" by number of long setae on second segment of maxillary palp [Ulmer, 1939: 618]; actually, number of these setae can vary individually, being different on left and right palps of the same individual. It is unclear, if the forms, described as "Choroterpides major" and "Choroterpides exigua", belong to the same species or to different ones. Two other species of Dilatognathus are described as larvae Choroterpes (Dilatognathus) minor (Dang, 1967 [Choroterpides]) comb. n. from Vietnam and Choroterpes (Dilatognathus) nigella (Kang et Yang, 1994 [Choroterpides]) comb. n. from Taiwan.

The species described as male imago from Hainan (China) under the name Choroterpides hainanensis You et Gui, 1995 has unclear systematic position.
Besides Ch. (D.) cataractae sp.n. and species from Java, I have examined larvae of Dilatognathus from Thailand and Hainan.

\subsection{3-1. Dilatognathus/g(1) cataractae sp.n. [Choroterpes] \\ Figs 129-133}

Original binomen: Choroterpes (Dilatognathus) cataractae sp.n. Possible binomina:

- Choroterpes (Dilatognathus) cataractae;

- Choroterpes (Euthraulus) cataractae;

- Euthraulus (Dilatognathus) cataractae;

- Dilatognathus cataractae.

MATERIAL. Holotype: L-S-I $\sigma^{7}\{$ No. [XXXIX] (6)] $\}$, Indonesia, Lombok, Senaru, under Sendang Gila waterfall, 25.IX.2009, coll. N. Kluge \& L. Sheyko. Peratypes: the same locality, 1926.IX.2009: 3 L-S-IO, 10 L-S-Iㅇ, 1 L-S $\sigma^{7}, 1$ L-S + , 49 larvae.

Larva. Cuticular COLORATION: Cuticle of head, pronotum and mesonotum brown, with diffusive markings; cuticle of legs and abdomen light brownish, nearly unicolorous, without contrasting markings.

Hypodermal COLORATION: Head and thorax with dark maculae. Fore protoptera with darkened proximal part of subcostal field. Abdomen and femora with brown pigmentation as in imago; tibiae light. Each tergalius has dorsal lamella dark brown, ventral lamella light brown.

ShAPE AND SETATION: Labrum (Fig. 133) has median incision very shallow, with shallow convexity in middle, denticles not expressed; proximal transverse row of setae [shifted proximally — see Dilatognathus (1)] interrupted medially; instead of distal transverse row, there is a wide stripe of irregularly situated setae, smaller than setae of the proximal transverse row; most part of dorsal surface with irregularly situated long and thin setae, somewhat smaller than setae of the distal stripe (not shown in Fig. 133). Other mouthparts as in Figs 129-131, 139. Legs as in Figs 147151: Femur of fore leg widest proximally, femora of middle and hind legs widest at middle. Femora with irregularly situated stout setae of various length; dorsal side of fore femur with a few setae, dorsal side of middle and hind femora with many setae. Ventral side of hind femur with a stripe of irregularly situated curved pectinate setae (Figs 150-151). Stout setae on inner side of fore tibia situated densely and irregularly, pointed and bipectinate (with two rows of stout pointed processes by sides). Inner side of middle and hind tibia with a sparse row of stout setae; outer side of hind tibia with stout setae of variable length, as on outer side of femur. Outer sides of all tibiae with irregularly situated thin hairs, whose length exceed tibia width (not shown in Figs 147-150). Abdomen without stout setae. Posterolateral spines short and obtuse. Hind margins of abdominal terga with very thin, spine-like denticles, whose size increases from tergum I to tergum $\mathrm{X}$; lateral parts of terga I-VIII lack denticles; sterna lack denticles. Hind margins of segments of caudalii with spine-like denticles and whorls of stout setae, whose length does not exceed length of segment. Tergalii II-V have equal size and shape (Fig. 140), tergalius VI smaller, tergalius VII smallest and lacks costal process of dorsal lamella (Fig. 138); analproximal projection of ventral lamella poorly expressed on tergalius II (Fig. 140), better developed on tergalii III-VII (Figs 141, 138). Protogonostyli of male larva short and narrowly separated; protopenes convergent, completely hidden under sternum XI (Fig. 144). Female larva has hind margin of abdominal sternum IX slightly incised (Fig. 143).

Subimago. Cuticular COlORATION: Cuticle of thorax at most light with brown sclerites; mesonotum at most brown; 

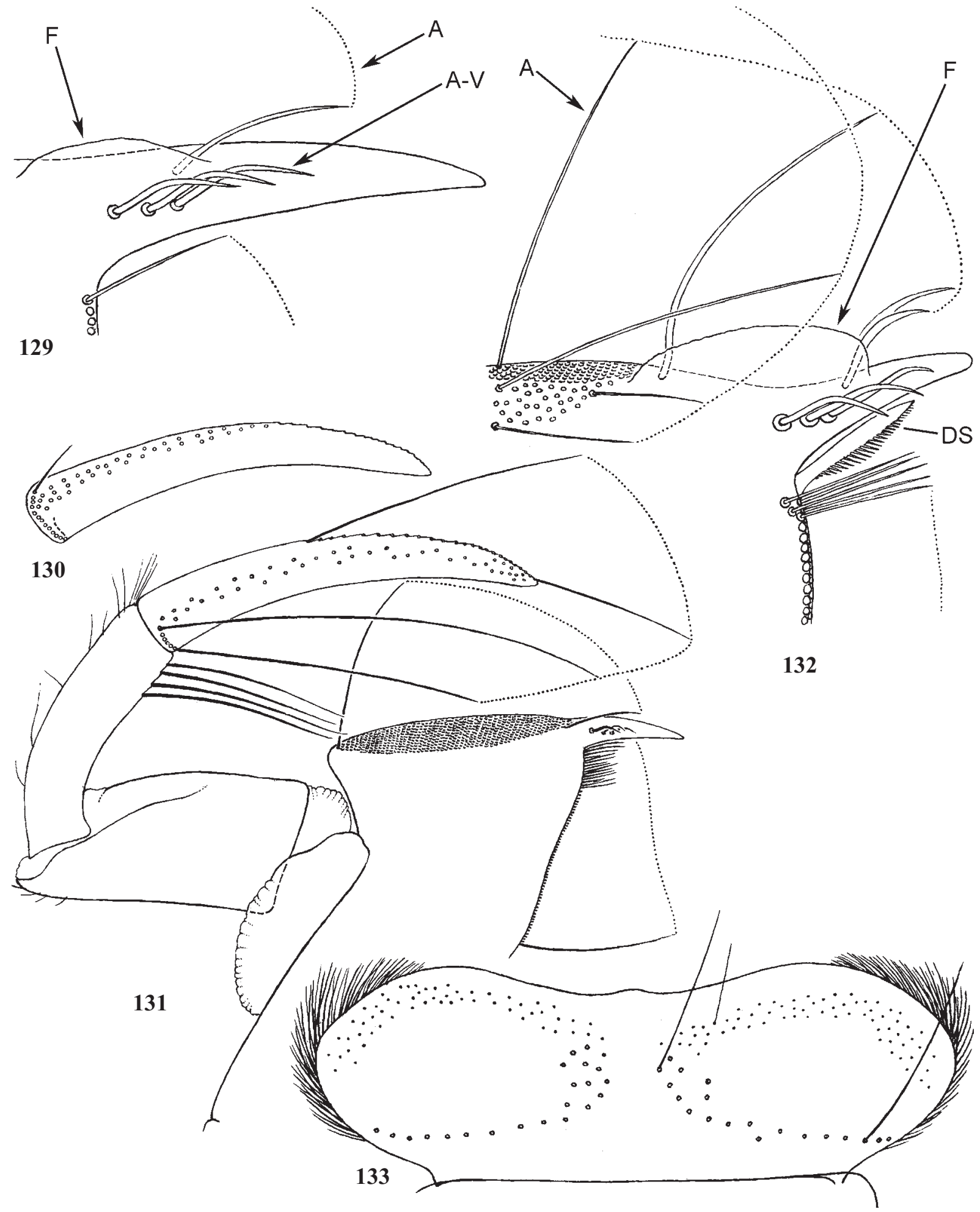

Figs 129-133. Choroterpes (Dilatognathus) cataractae sp.n.: 129-132 — maxillae (instead of most setae, only their bases and tips are shown): 129-131 — maxilla of last instar larva: 129 - apex, ventral view; $130-3^{\text {rd }}$ segment of maxillary palp, dorsal view; 131 — ventral view; 132 apex of maxilla of penultimate instar larva, ventral view; 133 — labrum (holotype), dorsal view (most of setae on dorsal surface not shown; bases of setae of proximal transverse row shown as rings; bases of setae of distal transverse stripe shown as dots; other setae of dorsal surface not shown).

Рис. 129-133. Choroterpes (Dilatognathus) cataractae sp.n.: 129-132 - максиллы (вместо большинства щетинок показаны только их основания и вершины): 129-131 — максилла личинки последнего возраста: 129 — вершина, вентрально; 130 — 3 -й членик максиллярного щупика, дорсально; 131 - вентрально; 132 - вершина максиллы личинки предпоследнего возраста, вентрально; 133 - верхняя губа (голотип), дорсально (большая часть щетинок на дорсальной поверхности не показана; основания щетинок проксимального поперечного ряда показаны колечками; основания щетинок дистального поперечного ряда показаны точками; прочие щетинки дорсальной поверхности не показаны). 


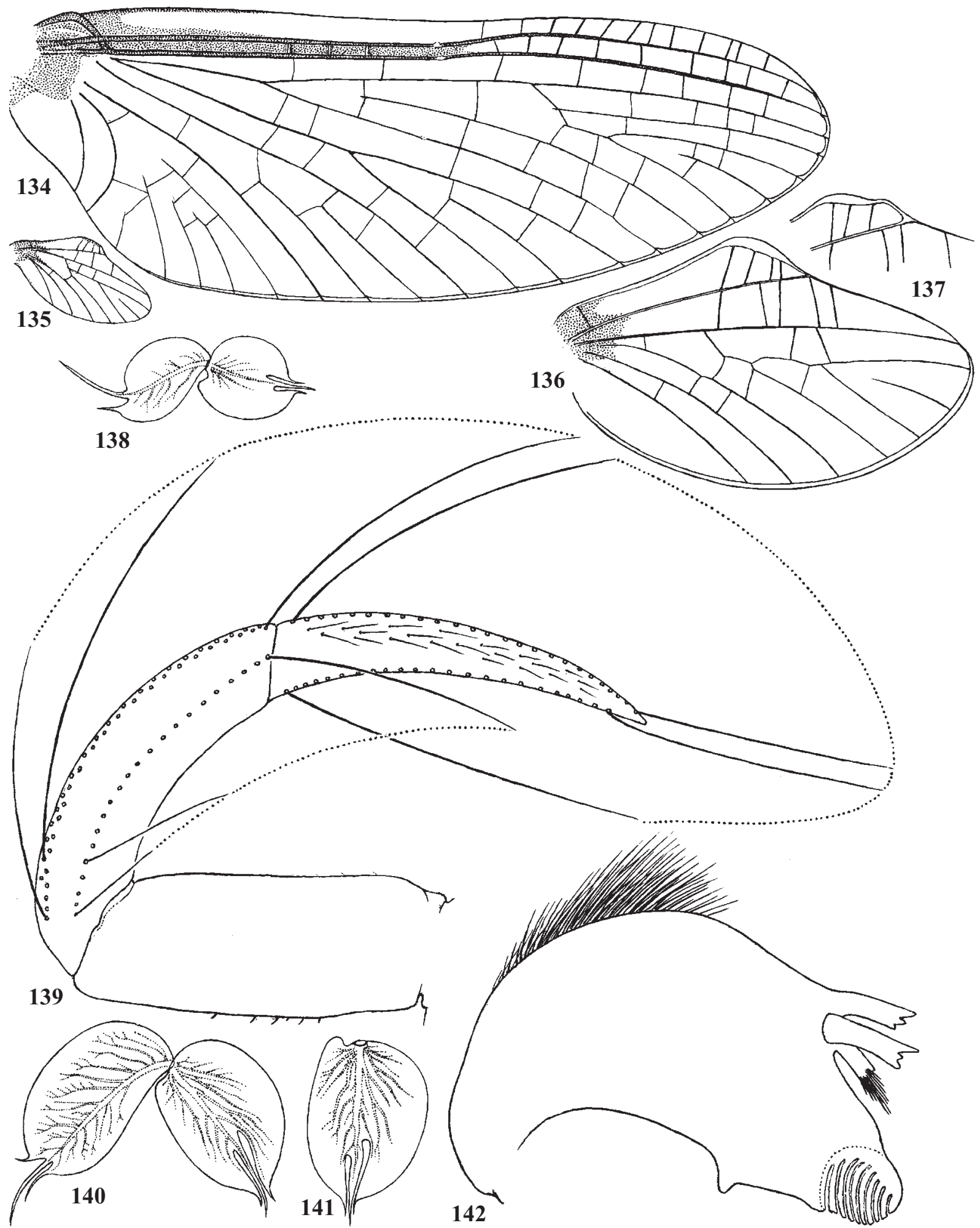

Figs 134-142. Choroterpes (Dilatognathus) cataractae sp.n.: 134-135 — fore and hind wings (holotype); 136 — hind wing; 137 costal projection of hind wing, another specimen; 138 — tergalius VII (dorsal lamella bent to the left); 139 — labial palp, ventral view (instead of most setae, only their bases and tips are shown); 140 — tergalius II (dorsal lamella bent to the left); 141 — ventral lamella of tergalius III; 142 - left mandible.

Рис. 134-142. Choroterpes (Dilatognathus) cataractae sp.n.: 134-135 — переднее и заднее крылья (голотип); 136 — заднее крыло; 137 - костальный выступ заднего крыла, другой экземпляр; 138 - VII тергалия; 139 - нижнегубной щупик, вентрально (вместо большинства щетинок показаны только их основания и вершины); 140 - II тергалия (дорсальный листок отогнут влево); 141 вентральный листок III тергалии; 142 — левая мандибула. 


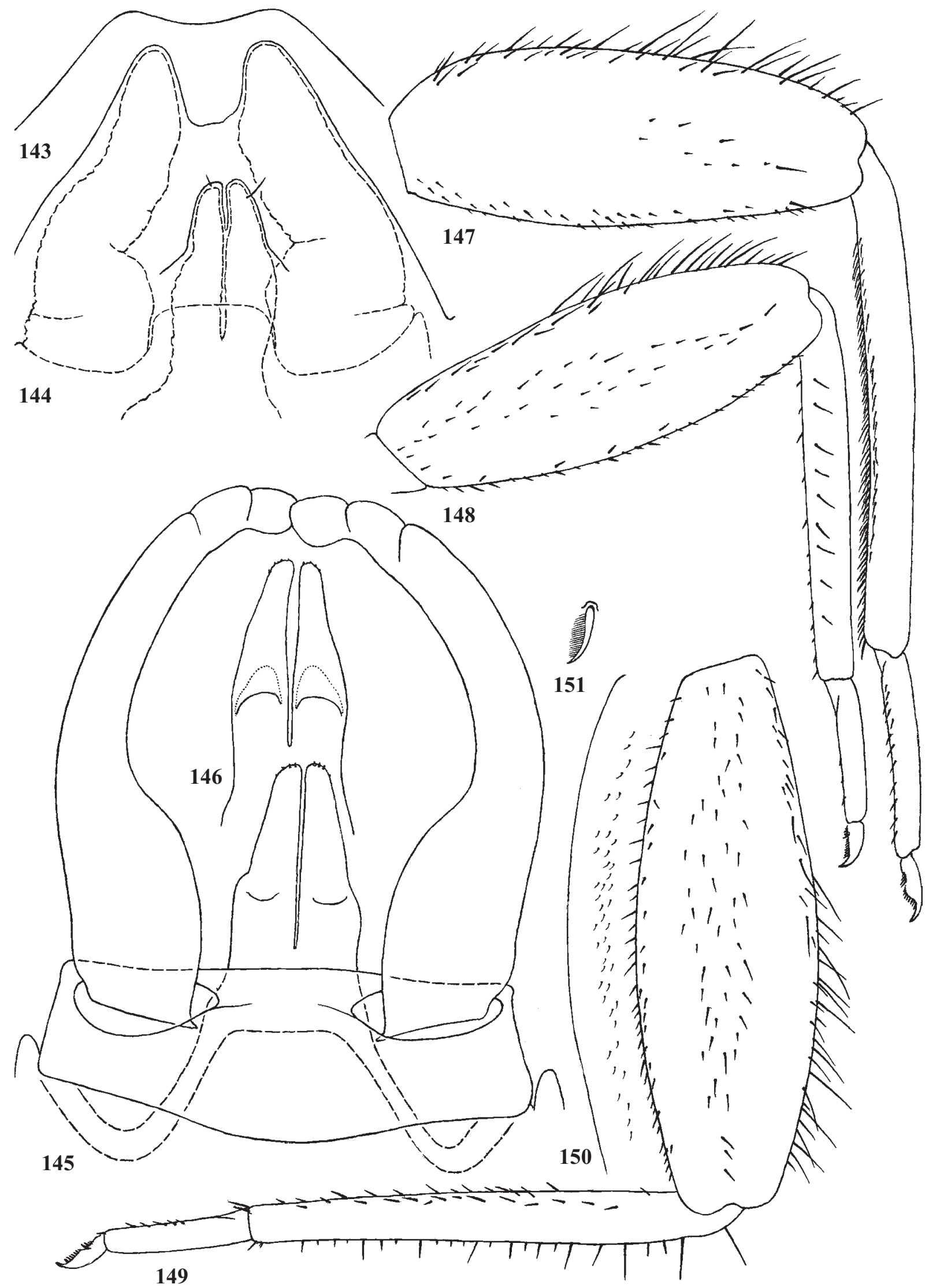


most part of medioscutum and submedioscutum brown, posterior scutal protuberance brown except median margin (as in Fig. 92). Cuticle of legs light, with diffusive brownish stripes. Wings light brownish. Cuticle of abdominal terga light brownish; abdominal sterna I-VIII colorless; sternum IX light brownish anteriorly and laterally, with colorless semicircular area medially-posteriorly; cuticle of gonostyli light brownish.

Hypodermal COLORATION: Abdomen and femora with brown coloration as in imago.

TeXTuRE: On each leg $1^{\text {st }}$ tarsomere (shortened and fused with tibia) covered by microtrichiae of the same shape as microtrichiae on tibia; $2^{\text {nd }}-5^{\text {th }}$ tarsomeres covered by pointed microlepides.

Imago, male. Head brown with ocher; dorsal eyes not elevated [as in Kluge, 1984: Fig.22], brownish-orange. Thorax brown with ocher. On fore wing basal part, including costal brace, and subcostal field brown, other membrane colorless; thick veins light brown, thin veins colorless; pterostigma whitish, with about 12 simple crossveins (Fig. 134). Hind wing basally brown, with costal projection blunt (Figs 135-137). Legs with brown hypodermal pigmentation: each femur dark brown in middle part, somewhat lighter brown basally and apically; tibia lighter (varies from ocher to brown), basally darker brown; tarsus either of the same color as tibia, or lighter, sometimes colorless. Abdominal terga have non-contrasting brown hypodermal coloration: each abdominal tergum at most part light brown; posterior and lateral margins darker brown; anterior margin light; a pair of submedian and a pair of sublateral light blanks are integrated with light anterior margin; each tergum I-IX has a pair of longitudinally-oval light lateral blanks, corresponding to dorsal attachments of lateral dorso-ventral muscles. Sterna I-VIII lighter, abdominal ganglia tinged with light brownish. Abdominal sternum IX has light brown cuticular coloration anteriorly and laterally; medially with grayish-brown hypodermal coloration; styliger and gonostyli light brown. Styliger with straight posterior margin. $1^{\text {st }}+2^{\text {nd }}$ segments of gonostylus with inner margin shallowly convex. Penes brown; each penis has apical projection [see Choroterpes/fg2 (3)] moderately long, conic, slightly bent medially-dorsally; its denticles are very small (Figs 145-146). Caudalii light brown, with dark brown ring at each joining.

Imago, female. Coloration as in male. Posterior plate of abdominal sternum IX apically slightly incised, as in larva (as in Fig. 143).

Egg. Yellow, oval. Chorion bears evenly dispersed papillae and ridges going from one papilla to another [see Choroterpes/fg2 (1)]; papillae small, one pole bears larger papillae.

DIMENSION. Fore wing length $7.5-8 \mathrm{~mm}$.

DISTRIBUTION. Lombok Island.

COMPARISON. Male and female imagoes differ from other species by brown coloration of proximal part of subcostal field of fore wing.

\subsection{3-2. Dilatognathus/g(1) sp.1}

$?=$ Choroterpides major Ulmer, 1939.

MATERIAL. Indonesia, Java, Cibodas (= Tjibodas), pool under waterfall at southern side of golf field, 6-11.VIII.2009, coll. N. Kluge \& L. Sheyko: 23 larvae.

DISTRIBUTION. Java.

COMMENT. Nguyen \& Bae [2003] reported "Choroterpides major" from Vietnam; diagnosis, which they gave to this species, includes only characters common for all species of Dilatognathus, so presence of this species in Vietnam is not proven.

\subsection{3-3. ?Dilatognathus/g(1) sp.2}

= "Choroterpides exiguus" sensu Ulmer, 1939 (non Thraulus exiguus Eaton, 1884).

MATERIAL. Indonesia, Java, Bogor, botanic garden, 24.II.2008, at light, coll. V. Ivanov: $2 \mathrm{I}^{7}, 4 \mathrm{~S}^{7}, 1 \mathrm{~S}$.

\subsection{3-4. Dilatognathus/g(1) sp.3}

MATERIAL. Thailand: province Mae Hong Son, river Namlang near Lot Cave, 12.I.1998, coll. V. Ivanov: 13 larvae; province Muang Pai, river Pai, 11.I.1998, coll. V. Ivanov: 7 larvae; SW Chiang Mai, Doi-Ithanon, river Klang, 17.I.1998, coll. Grigorenko: 1 larva; natrional park Kaeng Krachan, river Pchetchabun, 26.II.2006, coll. M. Chertoprud: 4 larvae.

Larva differs from $C h$. (D.) cataractae sp.n. by the following features: fore femur widest near middle; tibiae with dark brown hypodermal coloration.

\subsection{3-5. Dilatognathus/g(1) sp.4}

MATERIAL. China, Hainan, Miao-Li, 19.XII.1957, coll. N. Andrianova: 7 larvae.

Larva differs from $C h$. (D.) cataractae sp.n. by wider femora of all legs, with setae longer.

\section{Leptophlebiid larvae with «Dilatognathus-type» mouthpart structure}

In some non-related taxa of Atalophlebolinguata larvae independently got mouthpart structure of «Dilatognathus-type». These taxa are: (1) Dilatognathus, belonging to Choroterpes/fg2 - see above; (2) Notophlebia Peters \& Edmunds, 1970 - Indian taxon of unclear phylogenetic position; (3) Hermanellognatha, belonging to New World taxon Hermanellonota [Kluge, 2008]; (4) Hagenulus/fg3 (= subgenus Hagenulus Eaton, $1882)$, belonging to New World taxon Hagenulus/fg2 (= genus Hagenulus s.1.) [Kluge, 1994]; (5) Ulmeritus/ g2 (= subgenus or genus Ulmeritus Traver, 1956, s.str.), belonging to Neotropical taxon Ulmeritus/g1 (= genus Ulmeritus s.1., including Ulmeritoudes Traver, 1959). Some characters of their mouthpart structure are shown in Table 1.

In all these taxa labrum is widened, and its proximal setal row (characteristic for Atalophlebopectinata) is

Figs 143-151. Choroterpes (Dilatognathus) cataractae sp.n.: 143 - outline of hind margin of abdominal sternum IX of mature female larva; 144 - larval protogonostyli and protopenis (dorsal view, shown by integral lines) with developing subimaginal genitals inside (shown by interrupted lines); 145 - genitals of male imago (ventral view); 146 - penis of another specimen (ventral view); $147-149$ - fore, middle and hind legs (dorsal view); 150 - inner margin of hind femur, ventral view; 151 — seta near inner margin of hind femur; 146-151 holotype

Рис. 143-151. Choroterpes (Dilatognathus) cataractae sp.n.: 143 - очертание заднего края IX стернита брюшка зрелой личинки самки; 144 - протогоностили и протопенис личинки (дорсально, показаны сплошными линиями) с развивающимися субимагинальными гениталиями внутри (показаны прерывистыми линиями); 145 — гениталии самца имаго (вентрально); 146 пенис другого экземпляра (вентрально); 147-149 - передняя, средняя и задняя ноги (дорсально); 150 - внутренний край заднего бедра, вентрально; 151 - щетинка около внутреннего края заднего бедра; 146-151 - голотип. 
Table 1. Mouthparts of «Dilatognathus-type» in five non-related taxa Таблица 1. Ротовой аппарат «Dilatognathus-type» в пяти неродственных таксонах

\begin{tabular}{|c|c|c|c|c|c|c|}
\hline & taxa & $\begin{array}{c}\text { Dilatognathus } \\
\text { (Figs 129-133, 139) }\end{array}$ & $\begin{array}{l}\text { Notophlebia } \\
\text { ult. \& juv. }\end{array}$ & $\begin{array}{c}\text { Hermanellognatha } \\
\text { ult. \& juv. }\end{array}$ & $\begin{array}{c}\text { Hagenulus/fg3 } \\
\text { ult. \& juv. }\end{array}$ & $\begin{array}{c}\text { Ulmeritus/g2 } \\
\text { ult. }\end{array}$ \\
\hline \multirow[b]{2}{*}{ labrum } & incision & wide & wide & narrow & wide & wide \\
\hline & proximal row & proximal & $\begin{array}{l}\text { proximal, } \\
\text { irregular }\end{array}$ & proximal & proximal & proximal \\
\hline mandible & outer margin & semicircular & semicircular & angulate & angulate & semicircular \\
\hline \multirow{7}{*}{ maxilla } & apical flange & \begin{tabular}{|l|l}
$\begin{array}{l}\text { lost (in young larva } \\
\text { shortened) }\end{array}$ \\
\end{tabular} & lost & lost & shortened or lost & shortened \\
\hline & dentiseta & $\begin{array}{l}\text { lost (in young larva } \\
\text { straight) }\end{array}$ & lost & lost & straight & lost \\
\hline & pectinate setae & vestigial & lost & lost & present & present \\
\hline & tusk & long, grows & long & $\begin{array}{l}\text { from short to long, } \\
\text { not grows }\end{array}$ & short or long, grows & long \\
\hline & $1^{\text {st }}$ palpomere & $\begin{array}{l}\text { strengthened, } \\
\text { elongated }\end{array}$ & strengthened & $\begin{array}{l}\text { strengthened, } \\
\text { shortened }\end{array}$ & strengthened & strengthened \\
\hline & $\begin{array}{l}2^{\text {nd }}+3^{\text {rd }} \\
\text { palpomere }\end{array}$ & elongated & elongated & elongated & elongated & elongated \\
\hline & $\begin{array}{l}\text { long setae on } \\
3^{\text {rd }} \text { palpomere }\end{array}$ & irregularly & transverse rows & transverse rows & irregularly & irregularly \\
\hline \multirow{4}{*}{ labium } & $2^{\text {nd }}$ palpomere & $\begin{array}{l}\text { elongated, no } \\
\text { muscles }\end{array}$ & $\begin{array}{l}\begin{array}{l}\text { shortened, with } \\
\text { muscle }\end{array} \\
\end{array}$ & $\begin{array}{l}\text { elongated, with } \\
\text { muscle }\end{array}$ & $\begin{array}{l}\text { elongated, no } \\
\text { muscles }\end{array}$ & \begin{tabular}{|l|}
$\begin{array}{l}\text { normal, no } \\
\text { muscle }\end{array}$ \\
\end{tabular} \\
\hline & $\begin{array}{l}\text { long setae on } \\
2^{\text {nd }} \text { palpomere }\end{array}$ & longitudinal rows & - & longitudinal rows & longitudinal rows & - \\
\hline & $3^{\text {rd }}$ palpomere & elongated & elongated & normal & normal (short) & normal (short) \\
\hline & $\begin{array}{l}\text { long setae on } \\
3^{\text {rd }} \text { palpomere }\end{array}$ & longitudinal rows & transverse rows & - & - & - \\
\hline
\end{tabular}

strongly shifted proximally; median incision of labrum can be either widened (in Dilatognathus, Notophlebia, Hagenulus/fg3 and Ulmeritus/g2) or not (in Hermanellognatha). Mandibles (whose shape is often coordinated with labrum width) are always flat and widened, with strongly convex outer margin, whose shape varies from semicircular to angulate.

Maxilla undergoes a strong modification: instead of the apical flange, the pectinate dentiseta [see Atalophlebomaxillata (1)] and the apical-ventral row of pectinate setae (characteristic for Leptophlebia/fg1 in general) (Fig. 2), its inner-apical angle gets a single long tusk. This tendency is variously expressed in various taxa. Apical flange is completely lost in Notophlebia and Hermanellognatha [Kluge, 2008: Fig. 37]. Among Hagenulus/fg3, the apical flange is lost in Hagenulus morrisonae Peters et Alayo, 1971 [Kluge, 1994: Fig. 32], while a shortened apical flange is retained in Hagenulus caligatus Eaton, 1882 [Peters, 1971: Fig. 152]. In Dilatognathus the apical flange is nearly lost in last larval instar (Fig. 129), but a shortened flange is retained in younger larva (Fig. 132). In Ulmeritus/g2 apical flange is retained, being somewhat shortened. Dentiseta (which in other Atalophlebomaxillata is curved apically - Figs 2, 4, 5) is either straight and parallel to the tusk, or absent: straight dentiseta is retained in both species of Hagenulus/fg3 [Kluge, 1994: Fig. 32] and in younger larvae of Dilatognathus (Fig. 132); dentiseta is completely lost in ultimolarva of Dilatognathus (Fig. 129), in young and old larvae of Notophlebia, Hermanellognatha [Kluge, 2008: Fig. 37] and at least in ultimolarva of Ulmeritus/g2 (whose younger larvae have not been examined by me). Apical-ventral row of pectinate setae is completely lost in Notophlebia and Hermanellognatha [Kluge, 2008: Fig. 37]; three vestigial setae, shifted to the tusk, are retained in Dilatognathus (Figs 129, 132); in Hagenulus/fg3 and Ulmeritus/g2 the pectinate setae are retained [Kluge, 1994: Fig. 32; Peters, 1971: Fig. 152; Dominguez, 1991: Fig. 9], being smaller, than in related taxa. Tusk is present in all these taxa, but its size varies. Particularly, in Dilatognathus the tusk grows from instar to instar, being in ultimolarva very long (Figs 129, 131); among Hagenulus/fg3, Hagenulus caligatus has tusk short [Peters, 1971: Fig. 152], while in Hagenulus morrisonae tusk grows from instar to instar, being in ultimolarva very long [Kluge, 1994: Fig. 32]. In Hermanellognatha the tusk seems not to change proportions from instar to instar; in some taxa of Hermanellognatha (e.g., all species of Traverella Edmunds, 1948) the tusk is small; in some others very long [Kluge, 2008: 37]. Some authors used length of the tusk as a generic character and established genera Hydrosmilodon Flowers \& Dominguez, 1992 and Hydromastodon Polegatto et Batista, 2007 for species of Hermanellognatha with especially long tusks. However, long tusks of the same shape independently evolved in several species of HermanellognathaNeedhamella/g1 and in one of two species of Hermanellognatha-Hylister/g(1) [Kluge, 2008].

Maxillary palp always has elongated $2^{\text {nd }}$ and $3^{\text {rd }}$ segments taken together. Its $3^{\text {rd }}$ segment always bears very long filtering setae, which are situated either irreg- 
ularly (in Hagenulus/fg3, Ulmeritus/g2 and Dilatognathus - Figs 130,131), or form many short regular transverse rows (in Notophlebia and Hermanellognatha) [Kluge, 2008: Fig. 37]. The $1^{\text {st }}$ segment (which bears muscles moving the second segment) is thickened and strengthened; it can be either shortened (e.g., in Hermanellognatha), or, vice versa, elongated (e.g., in Dilatognathus - Fig. 131).

Labium always has paraglossae widened and strongly expanded laterally [Peters \& Edmunds, 1970: Fig. 165, 171; Peters, 1971: Figs 143, 144; Dominguez \& Flowers, 1989: Figs 46, 59, 70, 81; Dominguez, 1991: Fig. 13]. Labial palp can be either non-modified (in Ulmeritus/g2), or modified as filtering, in addition to filtering maxillary palp. In this case its $2^{\text {nd }}$ and $3^{\text {rd }}$ segments taken together are elongated and bear long filtering setae. But ways, how this effect is reached, vary among taxa: in Dilatognathus both $2^{\text {nd }}$ and $3^{\text {rd }}$ segments are elongated and bear longitudinal rows of filtering setae (Fig. 139); in Hagenulus/fg3 only $2^{\text {nd }}$ segment is elongated and bears longitudinal rows of filtering setae, while $3^{\text {rd }}$ segment is short, as in all Hagenulus/fg2 [Kluge, 1994: Fig. 25]; in Notophlebia, vice versa, $2^{\text {nd }}$ segment is strongly shortened and lost setation, while $3^{\text {rd }}$ segment is strongly elongated and bears numerous transverse rows of filtering setae.

Thus, in five non-related taxa the same combination of mouthpart modification occurs: (1) labrum and mandibles are widened; (2) on labrum proximal transverse row of setae is shifted proximally; (3) inner-apical angle of maxilla is more or less simplified and strengthened; (4) maxillary palp gets this or that filtering specialization; (5) paraglossae of labium are widened; (6) labial palp can get this or that filtering specialization. Adaptive role of this combination of mouthparts modification is unclear.

ACKNOWLEDGEMENT. Author thanks Boris Kondratieff (Colorado State University) for material on oklahoma [Choroterpes]. This investigation was supported by the Russian Federal Program for Support Leading Scientific Schools, grant No. 332.2010.4

\section{References}

Agnew J.D. 1962. New Leptophlebiidae (Ephem.) from the Transvaal // Archiv für Hydrobiologie. Vol.58. P.357-366.

Allen R.K. 1974. Neochoroterpes, a new subgenus of Choroterpes Eaton from North America (Ephemeroptera, Leptophlebiidae) // Canadian Entomologist. Vol.106. No.2. P.161-168.

Barnard K.H. 1932. South African May-flies (Ephemeroptera) // Trans. Roy. Soc. S. Afr. Vol.20. P.201-259.

Bauernfeind E. 1998. Taxonomie und Verbreitung von Choroterpes Eaton in der Palaearktis (Insecta: Ephemeroptera: Leptophlebiidae) // Stapfia. Bd.55. S.629-640

Demoulin G. 1981. Éphéméroptères // Durand J.-R. \& Lévêque C. (eds.). Flore et faune aquatiques de l'Afrique sahelo-soudanienne. Office de la Recherche Scientifique et Technique OutreMer, Collection Initiations - Documentations Techniques. No.45. P.407-443.

Domínguez E. 1991. The status of the genus Ulmeritus (Ephemeroptera: Leptophlebiidae: Atalophlebiinae) and related taxa // Alba-Tercedor J. \& Sanchez-Ertega A. (eds.). Overview and strategies of Ephemeroptera and Plecoptera (Proc. 6th Int. Congf. Ephemeroptera \& 10th Int. Symp. Plecoptera, 24-30 July 1989, Granada, Spain). Sandhill Crane Press. P.157173.

Domínguez E., Flowers R.W. 1989. A revision of Hermanella and related genera (Ephemeroptera: Leptophlebiidae: Atalophlebiinae) from Subtropical South America // Annals of the Entomological Society of America. Vol.82. No.5. P.555-573.

Eaton A.E. 1881. An announcement of new genera of the Ephemeridae // Entomologist's Monthly Magazine. Vol.17. P.191-197.

Eaton A.E. 1883-1888. A revisional monograph of recent Ephemeridae or mayflies // Transactions of the Linnean Society of London. Ser.2. Vol.3. P.1-352. P1.1-65.

Gaino E., Puig M.A. 1996. Choroterpes (Choroterpes) salamannai, a new species of mayfly from central and south west Spain. (Ephemeroptera Leptophlebiidae) // Bollettino della Società Entomologica Italiana. Vol.128. P.99-104.

Gattolliat J.-L., Sartori M. 2008. Order Ephemeroptera // Arthropod Fauna of the UAE. Vol.1. P.47-83.

Gillies MT. 1957. New records and species of Euthraulus Barnard (Ephemeroptera) from East Africa and the Oriental Region // Proceedings of the Royal Entomological Society of London. Ser.B. Vol.26. P.43-48.

Grandi M. 1941. Contributi allo studio degli Efemerotteri italiani. II. Reperti su Choroterpes picteti (Eaton) // Bollettino dell'Istituto di Entomologia della R. Università di Bologna. Vol.12. P.179-205.

Haybach A. 2003. Eistructuren bei deutschen Eintagsfliegen (Insecta: Ephemeroptera) — eine Überblick // Lauterbornia. Vol.47. S.41-58.

Henry B.C., jr. 1993. A revision of Neochoroterpes (Ephemeroptera: Leptophlebiidae), new status // Transactions of the American Entomological Society. Vol.119. No.4. P.317-333.

Kimmins D.E. 1956. New species of Ephemeroptera from Uganda // Bulletin of the British Museum (Natural History), Entomology. Vol.4. No.2. P.69-87.

Kimmins D.E. 1960. The Ephemeroptera types of species described by A.E. Eaton, R. McLachlan and F. Walker, with particular reference to those in the British Museum (Natural History) // Bulletin of the British Museum (Natural History). Entomology. Vol.9. No.4. P.269-318.

Kluge N.J. 1984. [Mayflies of the subgenus Euthraulus Barn. (Ephemeroptera, Leptophlebiidae, genus Choroterpes) of the fauna of the USSR.] // Entomologicheskoe Obozrenie [Revue d'Entomologie de l'URSS]. Vol.63. No.4. P.722-728 (in Russian) // Entomological Review. Vol.64. No.2. P.56-62 (English translation).

Kluge N.J. 1994. A revision of Leptophlebiidae of Cuba (Insecta, Ephemeroptera) // Zoosystematica Rossica. Vol.2. No.2. P.247-285.

Kluge N.J. 2004. The phylogenetic system of Ephemeroptera. Kluwer Academic Publishers. 456 pp.

Kluge N.J. 2008. A new taxon Hermanellonota, or subtribe Hermanellini subtr.n. (Ephemeroptera, Leptophlebiidae, Hagenulini), with description of three new species from Peruvian Amazonia // Russian Entomological Journal. Vol.16 (for 2007). No.4. P.127-137.

Kluge N.J. 2009. Higher system of Atalophlebiinae (Leptophlebiidae) with description of three new species of Terpides s.l. from Peruvian Amazonia // Russian Entomological Journal. Vol.18. No.4. P. 243-256.

Kluge N.J. 2010. Circumscriptional names of higher taxa in Hexapoda // Bionomina. Vol.1. P.15-55.

Kluge N.J., Novikova E.A. 2011. Systematics of the mayfly taxon Acentrella (Ephemeroptera, Baetidae), with description of new Asian and African species // Russian Entomological Journal. Vol.20. No.1. P.1-56.

Kluge N.J. 2012 [Cladoendesis and a new look to evolution of insect metamorphosis]//Entomologicheskoe Obozrenie. Vol.91. No.1. P.63-78 (in Russian).

Nguyen V.V., Bae Y.J. 2003. The mayfly family Leptophlebiidae (Ephemeroptera) from Vietnam // Insecta Koreana. Vol.20. No.3-4. P.453-466. 
Peters W.L. 1971. A revision of the Leptophlebiidae of the West Indies (Ephemeroptera) // Smithsonian Contributions to Zoology. Vol.62. P.1-48.

Peters W.L., Edmunds G.F., Jr. 1964. A revision of the generic classification of the Ethiopian Leptophlebiidae (Ephemeroptera) // Transactions of the Royal Entomological Society of London. Vol.116. No.10. P.225-253.

Peters W.L., Edmunds G.F., Jr. 1970. Revision of the generic classification of the Eastern Hemisphere Leptophlebiidae
(Ephemeroptera) // Pacific Insects. Vol.12. No.1. P.157-240. Sartori M., Gillies M.T. 1990. Further records of mayflies (Insecta; Ephemeroptera) from the Arabian Peninsula. Leptophlebiidae and Baetidae // Fauna of Saudi Arabia. Vol.11. P.10-17.

Traver J.R. 1934. New North American species of mayflies (Ephemerida) // Journal of the Elisha Mitchell Scientific Society. Vol.50. No.1-2. P.189-254. Pl.16.

Ulmer G. 1939. Eintagsfliegen (Ephemeropteren) von den SundaInseln // Archiv für Hydrobiologie. Supplement 16. S.443-692. 